\title{
Cenozoic granitoids in the Dinarides of southern Serbia: age of intrusion, isotope geochemistry, exhumation history and significance for the geodynamic evolution of the Balkan Peninsula
}

\author{
Senecio Schefer • Vladica Cuetković • Bernhard Fügenschuh • Alexandre Kounov • \\ Maria Ovtcharova $\cdot$ Urs Schaltegger $\cdot$ Stefan M. Schmid
}

Received: 15 January 2010/ Accepted: 29 August 2010

(C) Springer-Verlag 2010

\begin{abstract}
Two age groups were determined for the Cenozoic granitoids in the Dinarides of southern Serbia by high-precision single grain $\mathrm{U}-\mathrm{Pb}$ dating of thermally annealed and chemically abraded zircons: (1) Oligocene ages (Kopaonik, Drenje, Željin) ranging from 31.7 to $30.6 \mathrm{Ma}$ (2) Miocene ages (Golija and Polumir) at 20.58-20.17 and 18.06-17.74 Ma, respectively. Apatite fission-track central ages, modelling combined with zircon central ages and additionally, local structural observations constrain the subsequent exhumation history of the magmatic rocks. They indicate rapid cooling from above $300^{\circ} \mathrm{C}$ to ca. $80^{\circ} \mathrm{C}$ between 16 and $10 \mathrm{Ma}$ for both age groups, induced by extensional exhumation of the plutons located in the footwall of core complexes. Hence, Miocene magmatism and core-complex formation not only affected the Pannonian basin but also a part of the mountainous areas of
\end{abstract}

S. Schefer $(\bowtie) \cdot$ A. Kounov · S. M. Schmid

Geologisch-Paläontologisches Institut,

Bernoullistrasse 32, 4056 Basel, Switzerland

e-mail: senecio.schefer@unibas.ch

V. Cvetković

Univerzitet u Beogradu, Rudarsko Geološki Fakultet,

Đušina 7, 11000 Beograd, Republic of Serbia

B. Fügenschuh

Institut für Geologie und Paläontologie,

Innrain 52, 6020 Innsbruck, Austria

M. Ovtcharova - U. Schaltegger

Section des sciences de la Terre et de l'environnement,

Rue des Maraîchers 13, 1205 Geneva, Switzerland

Present Address:

S. M. Schmid

Institut für Geologische Wissenschaften,

FU Berlin, 12249 Berlin, Germany the internal Dinarides. Based on an extensive set of existing age data combined with our own analyses, we propose a geodynamical model for the Balkan Peninsula: The Late Eocene to Oligocene magmatism, which affects the Adriaderived lower plate units of the internal Dinarides, was caused by delamination of the Adriatic mantle from the overlying crust, associated with post-collisional convergence that propagated outward into the external Dinarides. Miocene magmatism, on the other hand, is associated with core-complex formation along the southern margin of the Pannonian basin, probably associated with the W-directed subduction of the European lithosphere beneath the Carpathians and interfering with ongoing Dinaridic-Hellenic back-arc extension.

Keywords Periadriatic intrusions - Granitoids · Dinarides · U-Pb dating · Hf isotopes .

Fission-track analysis

\section{Introduction}

Paleogene magmatic rocks within the Alpine-CarpathianPannonian-Dinaridic region occur in linear zones that surround the Adriatic plate (Periadriatic intrusions s.l.). At closer inspection, three such linear zones can be distinguished (Fig. 1 and Kovács et al. 2007): (1) a belt that follows the Periadriatic line delimiting the Southern Alps from the rest of the Alps (Periadriatic intrusions s.str.; e.g. Rosenberg 2004), (2) an alignment along the MidHungarian fault zone located within the Pannonian basin (e.g. Benedek 2002), and (3) a belt that follows the innermost Dinarides and extends across Bulgaria and northern Greece all the way to NW Turkey (e.g. Pamić et al. 2002a; Burchfiel et al. 2008). The distribution of the 


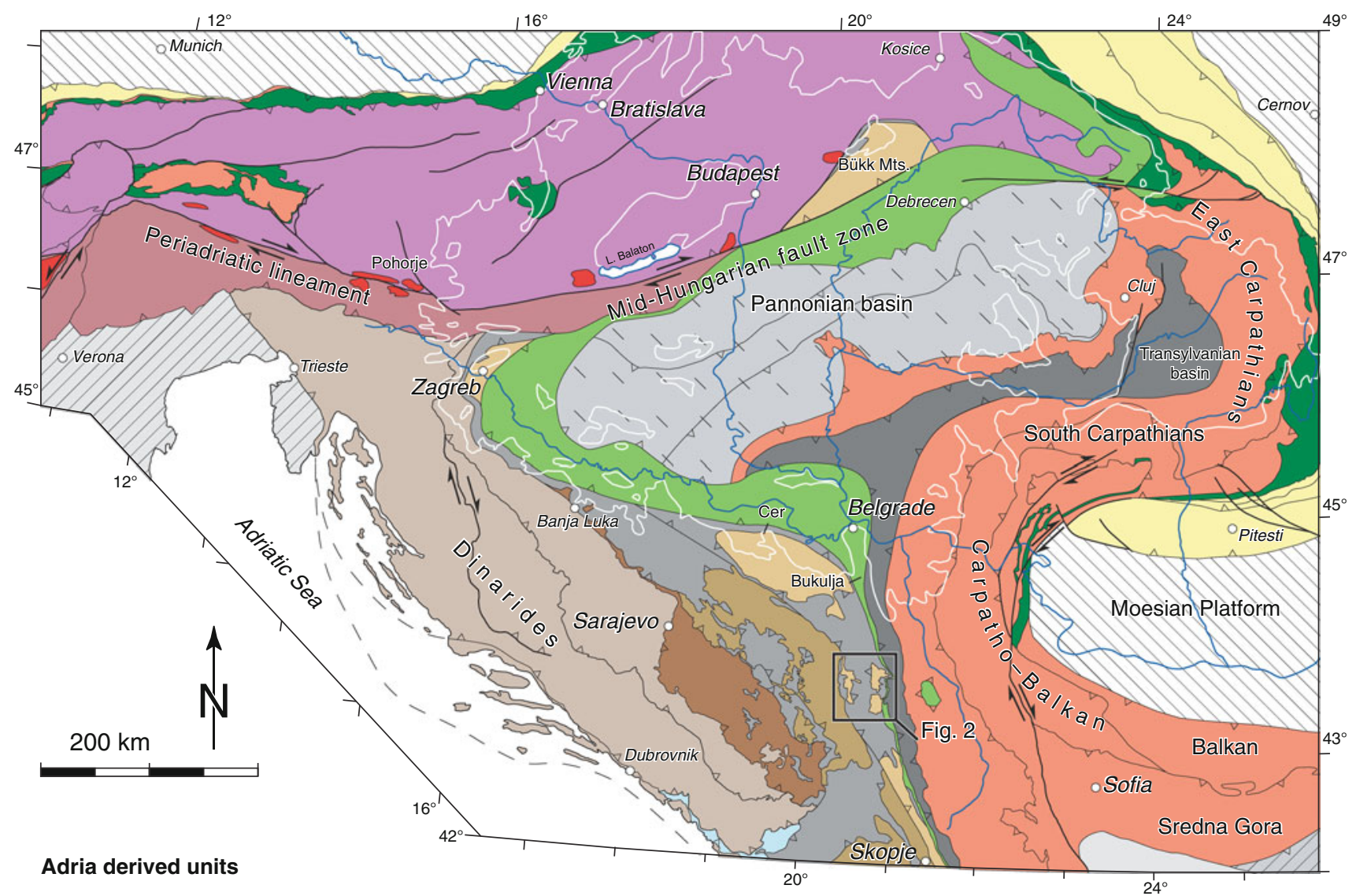

Western Vardar Ophiolitic Unit Jadar-Kopaonik-Studenica thrust sheet Drina-Ivanjica thrust sheet

East-Bosnian-Durmitor thrust sheet

External Dinarides (undifferentiated) Budva-Cukali Zone

ALCAPA Mega-unit

Southern Alps

Adriatic plate (undeformed)
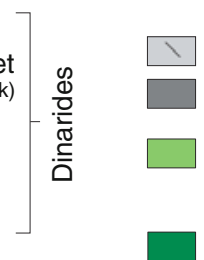

Tisza Mega-Unit

Eastern Vardar ophiolites

Sava zone (Neotethys suture) incl. Szolnok

oceanic rocks (undifferenciated)

Strandja Unit Rhodopes
Europe derived units

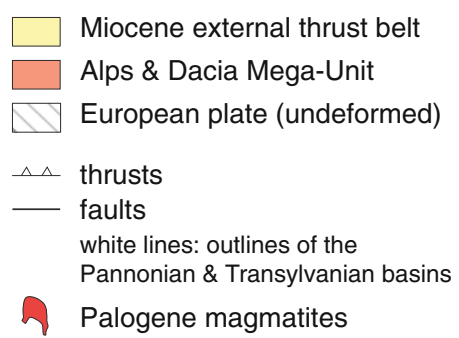

Fig. 1 Tectonic map of the Alps, Carpathians, and Dinarides, modified after Schmid et al. (2008). Note that only the Paleogene magmatites aligned along the Periadriatic lineament and the Mid-

Neogene magmatic rocks within the Alpine-CarpathianPannonian-Dinaridic region, on the other hand, is by far more dispersed, many but by no means all of them being related to subduction in the Carpathians and the contemporaneous opening of the Pannonian basin (e.g. Seghedi et al. 2004). Only rarely is the Neogene magmatic activity spatially associated with Paleogene precursors, such as in the Pohorje region of Slovenia (Trajanova et al. 2008). The Neogene granites of Mt. Bukulja and Mt. Cer in northern Serbia have been studied by Karamata et al. (1992), Cvetković et al. (2007a), and Koroneos et al. (2010), and their petrogenesis has been attributed to the Pannonian extension. However, the Cenozoic granitoids in southern
Hungarian fault zone are shown in this figure (Kovács et al. 2007). Regarding the Paleogene magmatites within the entire Balkan Peninsula see map of Fig. 9

Serbia that are subject of this study remained very poorly studied in terms of their age and geodynamic significance.

This paper presents the results of high-precision dating and Hf isotope analyses of the southern Serbian Kopaonik, Drenje, Željin, Golija, and Polumir intrusions (Fig. 2). These data are complemented by zircon and apatite fissiontrack data together and structural observations.

Additionally, the potential magmatic sources and the geodynamic setting of the Cenozoic intrusions in Serbia will be discussed within the frame of the entire Balkan Peninsula and adjacent areas, based on a recent compilation of tectonic units (Schmid et al. 2008). In particular, we shall discuss the much debated question as to whether the 


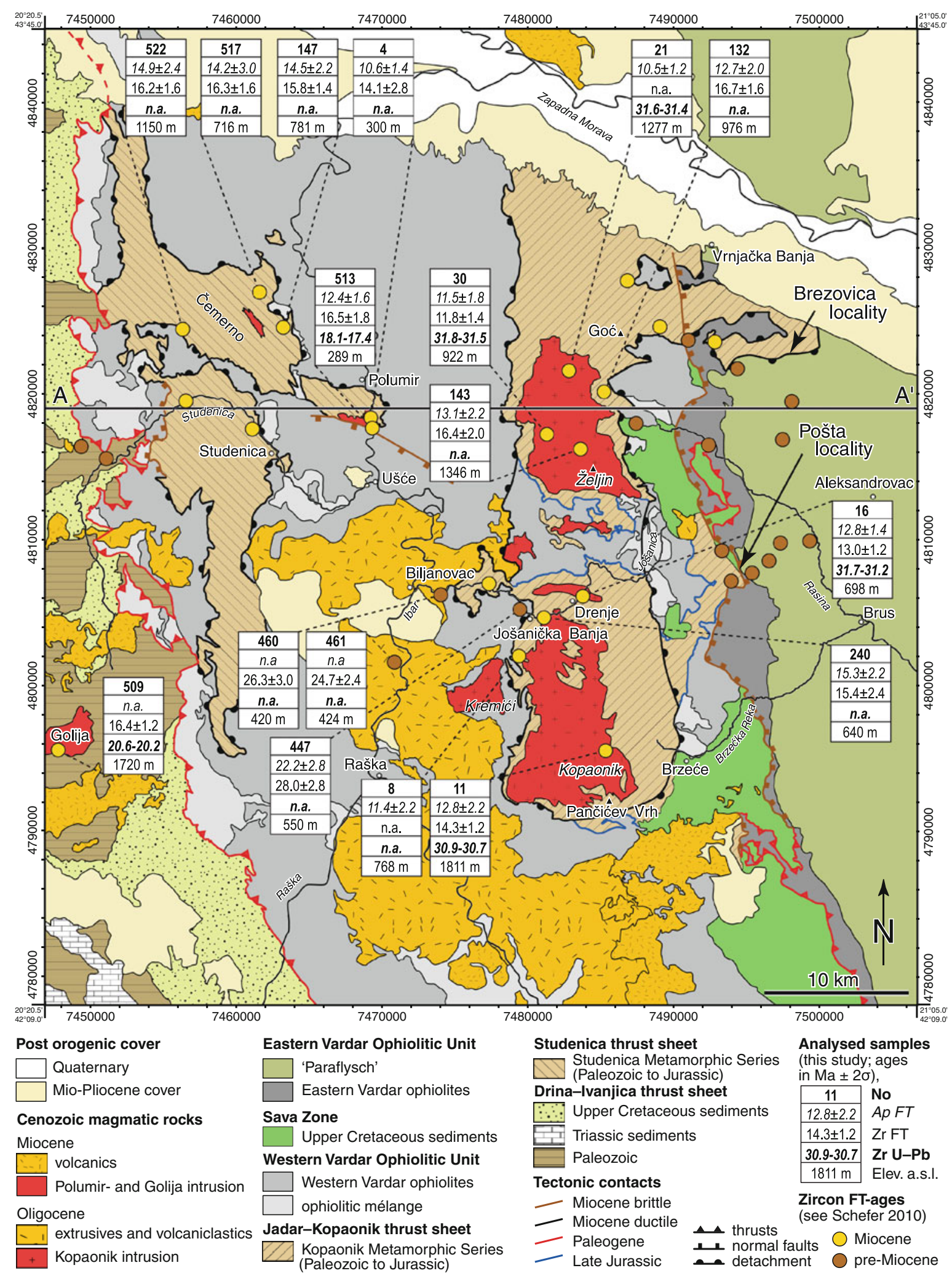

Fig. 2 Tectonic map of the Kopaonik area with $\mathrm{U}-\mathrm{Pb}$ and fissiontrack ages of the analysed samples (Tables 2 and 4), based on mapping by Schefer (2010) and on the Basic Geological Map of Yugoslavia (1:100’000), Sheets Novi Pazar (Urošević et al. 1970a), Vrnjci (Urošević et al. 1970b), Sjenica (Mojsilović et al. 1978), and
Ivanjica (Brković et al. 1976) as well as Simić (1956) for the Studenica area. Numbers at the border of the map are MGI Balkan 7 Cartesian coordinates. 'Miocene' and 'pre-Miocene' zircon ages are unpublished data from Schefer (2010) 
Paleogene Periadriatic intrusions of the Alps (Periadriatic intrusions s.str.) can be followed into the Mid-Hungarian fault zone and/or into the internal Dinarides and whether these intrusions represent the back-arc magmatism with respect to only one or two different subduction zones (Kovács et al. 2007), or alternatively, whether they are related to post-orogenic collapse of an overthickened crust in the internal Dinarides (Koroneos et al. 2010), mantle delamination and/or to extension in the Pannonian basin (e.g. Cvetković et al. 2007a). Sources for the magmatic activity in the Balkan Peninsula will be discussed by integrating the large amount of published age data on other granites and contemporaneous basaltic rocks (Cvetković et al. 2004a, b; Prelević et al. 2005). Also the formation of sedimentary basins, many of them associated with volcanics and/or volcaniclastics (e.g. Burchfiel et al. 2008), as well as information from seismic tomography (Piromallo and Morelli 2003), will be discussed in that context.

\section{Regional geology}

The Dinarides represent a complex orogen consisting of thrust sheets that contain ophiolitic as well as Adriaderived continental material. These thrust sheets are located in a lower plate position with respect to an upper plate formed by the Tisza and Dacia Mega-Units with European affinities (Schmid et al. 2008; Ustaszewski et al. 2009). Ophiolites, derived from the Vardar branch of the Neotethys Ocean (Fig. 1, 'Western Vardar Ophiolitic Unit'), were obducted already during the latest Jurassic onto the Adriatic margin and later involved in Late Cretaceous to early Paleogene out-of-sequence thrusting. This led to the formation of a series of composite nappes that consist of continent-derived material in their lower part and ophiolitic material in the upper part.

The area around the Kopaonik massif in southern Serbia exposes the two innermost Dinaridic composite nappes, namely the Drina-Ivanjica and the Jadar-KopaonikStudenica composite thrust sheets (Figs. 1, 2; Schmid et al. 2008; Schefer et al. 2010). In the latest Cretaceous to Early Paleogene, these innermost Dinaridic thrust sheets collided with the already existing (pre-Turonian) Carpatho-Balkan orogen that is part of the Dacia Mega-Unit and constitutes the upper plate of a complex collision zone (Schmid et al. 2008). A separating suture zone (Sava Zone) runs along the eastern rim of the innermost Dinarides, that is along the nternal limit of the Jadar-Kopaonik-Studenica composite thrust sheet, and separates the Dinarides from the Carpatho-Balkan orogen (Fig. 1).

The N-S-trending mountain range in the wider Kopaonik area exposes a part of the Jadar-Kopaonik-Studenica thrust sheet as well as an exhumed deeper part of the deeper
Drina-Ivanjica thrust sheet, both exposed in tectonic windows below the obducted ophiolites (Figs. 1, 2). These windows are formed by the Kopaonik and the Studenica Metamorphic Series, which consist of metamorphosed Upper Paleozoic to Lower Jurassic sediments of the distal Adriatic margin (Schefer et al. 2010). They are overlain by a (Middle?)-Upper Jurassic ophiolitic mélange located below the obducted Western Vardar Ophiolitic Unit (Fig. 2). The two metamorphic series and the obducted ophiolites are unconformably overlain by post-Turonian sediments (Fig. 2; 'Upper Cretaceous sediments') that contain large olistoliths, including ophiolites and metamorphic rocks. This weakly metamorphosed N-S-trending 'Senonian' flysch belt, trending N-S along the eastern margin of the Kopaonik composite thrust sheet, is interpreted to represent the southern prolongation of the Sava zone, i.e. the suture between the internal Dinarides and the Carpatho-Balkan orogen (Ustaszewski et al. 2009; Ustaszewski et al. in press).

The Kopaonik Metamorphic Series east of the Ibar valley and the overlying Western Vardar Ophiolitic Unit were both intruded by the Kopaonik, Drenje and Željin granitoids (Fig. 2). Available structural data (Egli 2008; Schefer et al. 2008; Schefer 2010; Zelić et al. 2010) indicate that the intrusion of these plutons postdates three phases of compressive deformation associated with thrusting in the internal Dinarides and suturing with the adjacent Carpatho-Balkan orogen, but pre-dates a latest D4 extensional deformation event associated with movements along normal faults that, although not observed within the plutons, will be shown to have led to their final exhumation.

While extension postdates the intrusion of the Kopaonik, Drenje and Željin intrusions it is at least partly contemporaneous with the emplacement of the younger Polumir granite. Extension is manifested by the following structures: (1) N-S stretching by ductile extensional deformation is mainly observed in the Studenica valley and around the Polumir intrusion in the Ibar valley (labelled 'Miocene ductile' in Fig. 2), (2) ductile collapse folds characterized by sub-horizontal axial planes are found in the vicinity of the Kopaonik intrusion (Egli 2008), and (3) brittle E-W and N-S-trending normal faults (labelled 'Miocene brittle' in Fig. 2). Whereas ductile extension is exclusively associated with $\mathrm{N}-\mathrm{S}$ stretching, brittle extension occurs along two contemporaneously active sets that lead to extension in both $\mathrm{E}-\mathrm{W}$ and $\mathrm{N}-\mathrm{S}$ direction. Furthermore, N-S-striking brittle faults are seen to cut ductile E-W-striking faults, indicating that $\mathrm{E}-\mathrm{W}$-directed extension is younger. PostOligocene deformation is thus divided into two phases, an earlier ductile phase (D4a) and a later brittle phase (D4b).

A pronounced $\mathrm{N}-\mathrm{S}$-oriented stretching lineation and frequently observed boudins are the dominant macroscopic expression of the ductile D4a phase. Near Polumir locality 
Fig. 3 Structural features from the Polumir intrusion.

a Asymmetric boudinage indicating top-to-the-north extension (location 513 on Fig. 2). The stereoplot (lower hemisphere) compares stretching lineations from the dykes with those from the host rocks (Studenica Metamorphic Series) showing N-S movement syn- to post-intrusion of the Miocene Polumir granite. $L s=$ stretching lineation. $\mathbf{b}$ The dykes intrude at a later stage of the foliation, but become foliated in the same way as the host-rock, as can be observed along the margin of the dyke. c Leucocratic layers in the mylonitized host rocks, offset by discrete normal faults, indicating that deformation continued into the brittle field with a similar orientation of the principle stress-axes. d C-S structures in the main body of the Polumir granite indicate top-to-the-north extensional deformation. Penetrative associations of foliation and ductile shear-bands usually develop during a retrogressive history from high to medium temperature. This scenario suits well with a syntectonic emplacement of the intrusion (Gapais 1989)
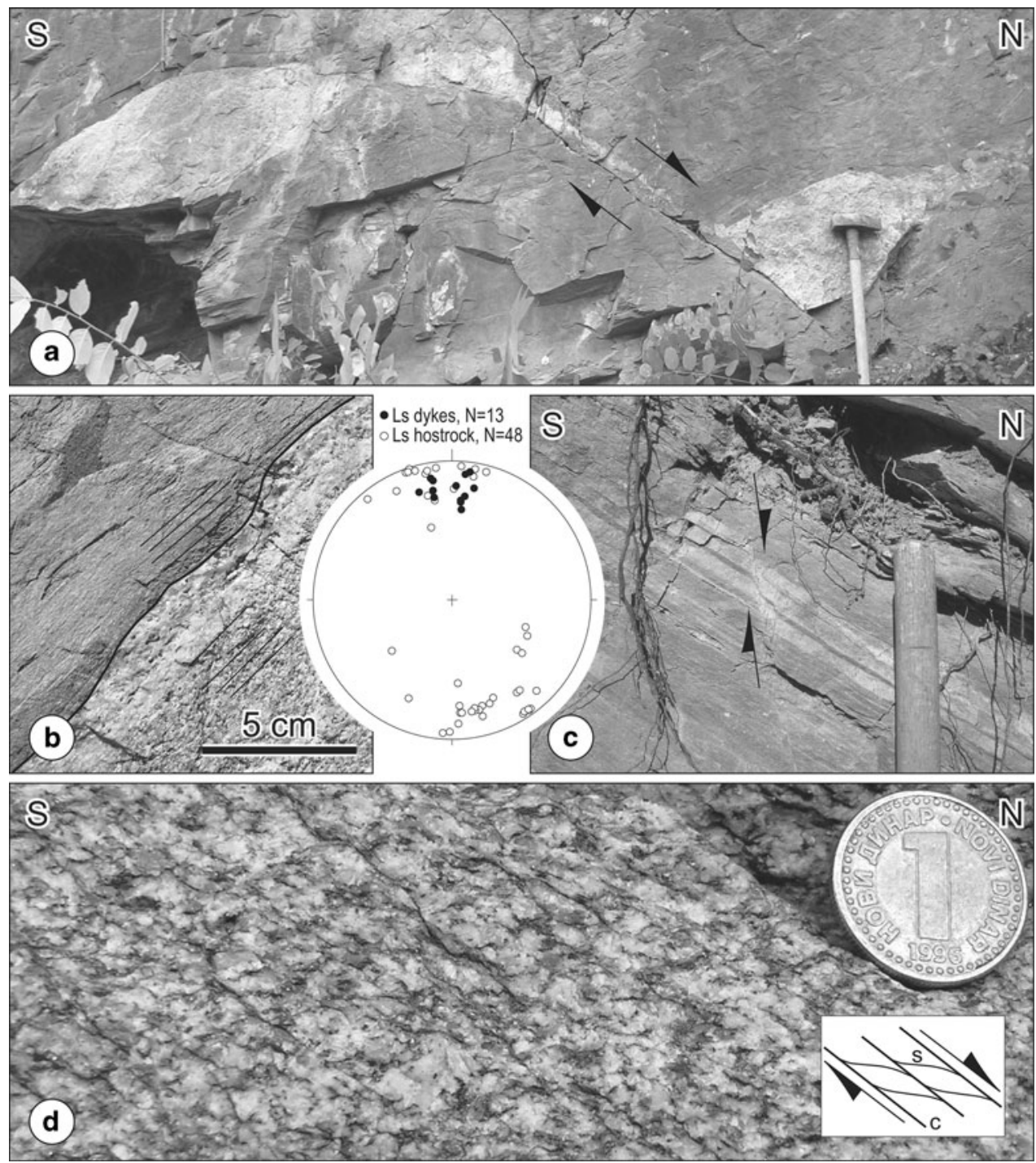

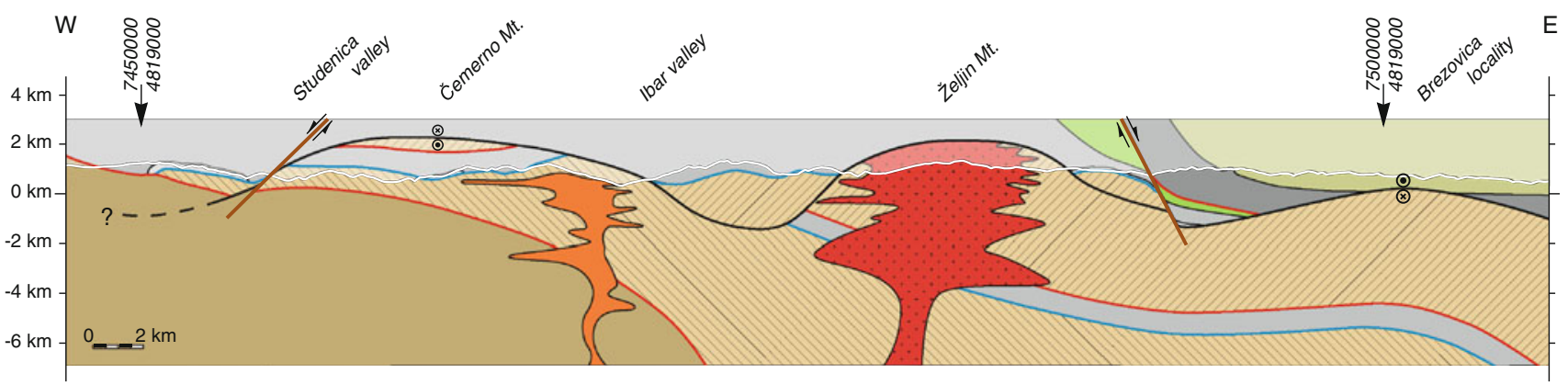

Fig. 4 E-W-oriented cross section across the entire study area; legend and trace of profile are shown on Fig. 2. Ages of main activity along the major tectonic contacts are colour-coded as in Fig. 2

in the Ibar valley (Fig. 2) the two-mica granite shows asymmetrically boudinaged dykes in the host rocks and $\mathrm{S}-\mathrm{C}-$ fabrics both indicating top-N shearing (Fig. 3a, d). The dykes are progressively deformed under decreasing temperatures as indicated by kinematically consistent ductile to brittle faulting (Fig. 3c, d).
$\mathrm{N}-\mathrm{S}$-oriented extension is substantial within the entire study area. In the Studenica area, this extension exhumes amphibolite-facies rocks in the form of a core complex (Fig. 4). At the Brezovica locality (Fig. 2), large-scale shear-bands found in meta-limestones of the Kopaonik Metamorphic Series exhume upper-most greenschist-facies 
rocks and bring them in contact with Cretaceous sediments referred to as 'Paraflysch' (cover of the Eastern Vardar ophiolitic Unit), thereby omitting the Eastern Vardar ophiolites, the Upper Cretaceous sediments of the Sava zone as well as the entire Western Vardar Ophiolitic Unit (see area around Brezovica locality in Fig. 2).

Brittle normal faults (D4b) are observed to affect all tectonic units throughout the entire study area at different scales. In many places, brittle normal faults are seen to crosscut ductile detachments formed during D4a. Smallscale normal faults, mainly expressed in serpentinized ophiolitic rocks, scatter in all directions. The major largescale brittle normal faults, however, are N-S striking. They border the core complexes of the Studenica valley and the mountain chain of Kopaonik and Željin (Fig. 4). In between the two domes of Kopaonik and Željin mountains, E-Wstriking brittle normal faults formed during D4b are also found (Fig. 2). The W-dipping D4b brittle normal fault at the western border of the Studenica dome is made up of several smaller faults that crosscut the former D4a detachment delimiting this core complex to the west. Ductilely deformed amphibolite-facies rocks are found in the footwall of this brittle normal fault whereas lower greenschist-facies rocks of the Studenica thrust sheet and formerly obducted ophiolitic rocks from the Western Vardar Ophiolitic Unit are exposed in its hanging wall (Figs. 2, 4). The offset in metamorphic grade across this brittle fault is thus substantial, but most of this offset probably has to be attributed the D4a ductile precursor that was associated with $\mathrm{N}-\mathrm{S}$ directed extension and core-complex formation during D4a (faults marked 'Miocene ductile' in Fig. 2).

An E-dipping brittle normal fault is found at a locality referred to as 'Pošta locality' in Fig. 2. This brittle fault zone shows a sharp contact to the hanging wall composed of fault gauges that include cataclastic fragments of ophiolitic rocks at its top, overprinting an older and more gently dipping foliation that might be associated with earlier N-S-oriented extension produced during D4a. Towards the base of the fault zone, the style of deformation changes from brittle to ductile, and an LS-tectonite exhibits top-E-oriented shear-bands.

The main Kopaonik pluton produced a contact metamorphic aureole consisting of hornfels and skarns that formed at $1-2 \mathrm{kbar}$ and ca. $550^{\circ} \mathrm{C}$ according to Knežević et al. (1995). The Studenica Metamorphic Series that crop out in a window west of the Ibar valley are intruded by the Polumir granite (Fig. 2). The Polumir granite shows hightemperature ductile deformation along its intrusive margin. The Golija granodiorite, located further west of the main thrust that separates the Jadar-Kopaonik-Studenica and Drina-Ivanjica composite thrust sheets, intruded Upper Paleozoic slates, siltstones, and sandstones of the DrinaIvanjica composite thrust sheet (Fig. 2).
Suites of Oligocene to Miocene volcanic and volcaniclastic rocks are associated with these intrusions, representing their effusive equivalents. Most of the Oligocene volcanics intrude and/or overlie the ophiolites. They are confined to the Ibar Valley (Fig. 2) and are predominantly represented by extrusive to autoclastic dacitic/andesitic rocks. By contrast, the Miocene volcanics are quartzlatitic in composition and are represented by effusive and pyroclastic rocks. The latter were related to Plinian to subPlinian events and ignimbrite formation. The Miocene volcanic rocks occur in the surroundings of the Golija pluton as well as southeastward from the Kopaonik intrusives (Fig. 2). These rocks are poorly studied in contrast to their counterparts in the north (Cvetković and Pécskay 1999; Cvetković 2002).

Whereas the petrography of these intrusions and related volcanics is rather well known (e.g. Knežević et al. 1995; Vukov 1995), the geochronology is not yet well documented and high-precision U-Pb analyses are altogether missing. In a number of reviews (e.g. Karamata et al. 1992; Knežević et al. 1995; Prelević et al. 2001), the intrusive rocks of southern Serbia were separated into two different groups based on mineral and whole rock K-Ar ages: An Oligocene group including Kopaonik and its satellite Kremići and a Miocene group comprising the Željin, Golija, Drenje, and Polumir intrusions (Fig. 2). While according to the existing literature, the Oligocene group is regarded to represent I-type granites (Karamata et al. 1992; Knežević et al. 1995), the presumed Miocene group supposedly consists of both I-type (Željin, Golija and Drenje; Karamata et al. 1992) and S-type granitoids (Polumir; Vukov 1995; Vukov and Milovanović 2002). However, similarities in style of intrusion, as well as the close neighbourhood of the Kopaonik, Drenje, and Željin intrusions, suggest that they might be closely related and cogenetic. Cvetković et al. (2002), based on geochemical data, even proposed a co-magmatic evolution of the Kopaonik and Drenje intrusives, although this suggestion was in conflict with differences in their $\mathrm{K}$-Ar radiometric ages as reported by Delaloye et al. (1989). Hence, at least part of the K-Ar age data seems suspicious and thus need closer inspection.

\section{Petrography and chemical composition of the granitoids}

Kopaonik and Drenje intrusive(s)

The Kopaonik intrusive displays a zonal distribution of granitoid varieties that show gradual transitions between each other (Zelić 2004; Cvetković et al. 2002). The southern part is represented by porphyritic granodiorite to quartzmonzonite characterized by the presence of large 


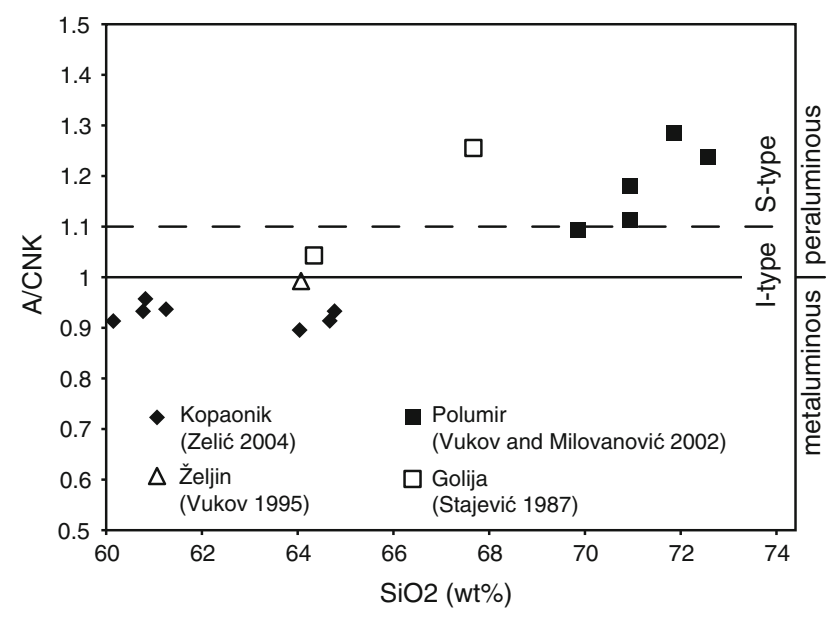

Fig. 5 Diagram showing the $\mathrm{Al}_{2} \mathrm{O}_{3} / \mathrm{NaO}+\mathrm{K}_{2} \mathrm{O}+\mathrm{CaO}$ vs. $\mathrm{SiO}_{2}$ relationships. Reference value for distinguishing peraluminous from metaluminous rocks after Shand (1947), reference value for distinguishing I- and S-types after Chappell and White (1974)

$\mathrm{cm}$-sized potash feldspars. Towards the north, the intrusive rocks are more equigranular in texture and granodioritic to quartzdioritic in composition. The Drenje intrusion crops out as a separate, E-W elongated body, which is essentially similar to the equigranular granodiorite of the northern part of the Kopaonik pluton. In general, these granitoids are composed of quartz, plagioclase $\left(\mathrm{An}_{35-55}\right)$, potash feldspar $\left(\mathrm{Or}_{>86}\right)$, biotite, and magnesiohornblende, with titanite, epidote, allanite, apatite, zircon, and magnetite as accessory minerals. Decimetre-sized mafic enclaves are observed in all the varieties albeit with some differences. In the southern area, they are larger and highly irregular in shape and sometimes contain felsic minerals apparently derived from the host granodiorite. These enclaves are typically biotite-rich and display a high-K composition. In the northern area, they are smaller, usually rounded and rich in amphiboles.

Most Kopaonik and Drenje rocks have silica contents ranging from 57 to $67 \mathrm{wt} \% \mathrm{SiO}_{2}$. They are medium-K calc-alkaline, metaluminous $\left(\mathrm{Al}_{2} \mathrm{O}_{3}-\left[\mathrm{K}_{2} \mathrm{O}+\mathrm{Na}_{2} \mathrm{O}\right]<1\right)$, I-type granitoid rocks (Fig. 5), with LILE- and LREEenriched trace element patterns. Because of slightly elevated $\mathrm{K}_{2} \mathrm{O}$ concentrations $(\geq 2.5-3 \mathrm{wt} \%)$, the Kopaonik quartzmonzonites occurring in the south exhibit a high-K calc-alkaline character and are richer in incompatible elements compared to the Kopaonik and Drenje granodiorites.

\section{Željin intrusive}

The Željin intrusive ranges in composition from predominant quartzdiorite, tonalite, and granodiorite to subordinate granite (Vukov 1989). These rocks show mineral compositions that are very similar to those of Kopaonik and Drenje, and they also show mutual compositional transitions characterized by increasing quartz and potash feldspar modal contents ranging from quartzdiorite to granite. Mafic enclaves are rare and more variable in composition compared to those from the Drenje intrusive.

The Željin quartzdiorite-granite suite is represented by typical medium-K calc-alkaline $\left(\mathrm{SiO}_{2}\right.$ mostly above $65 \mathrm{wt} \%$, $\mathrm{K}_{2} \mathrm{O} \leq 2 \mathrm{wt} \%$ ), metaluminous, I-type rocks (Fig. 5; Vukov 1995). They have almost identical geochemical characteristics to those of the Kopaonik and Drenje intrusives.

Golija intrusive

These granitoid rocks are represented by relatively small irregularly shaped bodies or small dyke-like shallow intrusions cutting Paleozoic rocks of the Drina-Ivanjica thrust sheet. The granitoid body formed a contact metamorphic aureole, to which small skarn-related deposits with iron, $\mathrm{Pb}-\mathrm{Zn}$, and wolfram mineralization are related (Mojsilović et al. 1980). The rocks are granodiorites to quartzmonzonites and have inequigranular hypidiomorphic textures. They contain quartz, potash feldspar, plagioclase (andesine), biotite, and amphibole, with tourmaline, allanite, sphene, apatite, and zircon as accessory minerals.

According to scarce literature data, these rocks are high-K calc-alkaline $\left(\mathrm{SiO}_{2}>65 \mathrm{wt} \%, \mathrm{~K}_{2} \mathrm{O} \geq 3 \mathrm{wt} \%\right)$, metaluminous $\left(\mathrm{Al}_{2} \mathrm{O}_{3}-\left[\mathrm{K}_{2} \mathrm{O}+\mathrm{Na}_{2} \mathrm{O}\right]<1\right)$ and possess I-type characteristics (Fig. 5). Therefore, they are geochemically similar but slightly more potassium rich in comparison to the Kopaonik, Drenje, and Željin granitoids (Mojsilović et al. 1980).

\section{Polumir granite}

This is a typical leucocratic two-mica granite composed of quartz, potash feldspar $\left(\mathrm{Or}_{82-93}\right)$, acid plagioclase $\left(\mathrm{An}_{<30}\right)$, biotite $\left(\mathrm{Al}_{2} \mathrm{O}_{3}>18 \mathrm{wt} \%\right)$, and muscovite. Apatite, magnetite, monazite, allanite, and zircon are the main accessory minerals. Plastic deformation along the intrusive margins, absent in case of all the other intrusions, resulted in a foliation formed by biotite and white mica.

In comparison with the other granitoid rocks, the Polumir granite is a more silica rich $\left(\mathrm{SiO}_{2}\right.$ mostly above 70 wt\%) peraluminous $\left(\mathrm{Al}_{2} \mathrm{O}_{3}-\left[\mathrm{K}_{2} \mathrm{O}+\mathrm{Na}_{2} \mathrm{O}\right]>1\right)$ S-type granitoid rock (Fig. 3). In addition, this granite has an overall lower content of incompatible elements, except for rubidium $(\mathrm{Rb} \sim 200$ ppm; Vukov and Milovanović 2002).

\section{$\mathrm{U}-\mathrm{Pb}$ (ID-TIMS) dating and Hf isotope data}

Analytical techniques

The analytical techniques of U-Pb dating closely follow those outlined in Schaltegger et al. (2008). Prior to analysis, 
the zircons were treated by annealing-leaching (chemical abrasion). This minimizes the effects of post-crystallization lead loss (Mattinson 2005). Calculation of ${ }^{206} \mathrm{~Pb} /{ }^{238} \mathrm{U}$ ages was done with the Isoplot/Ex v. 3 program (Ludwig 2005). The techniques of the $\mathrm{Hf}$ isotope analysis are those described in Schaltegger and Brack (2007). Mean ages and mean $\mathrm{Hf}$ isotopic values are given with uncertainties at the 95\% confidence level.

Sample material and presentation of the results

$\mathrm{U}-\mathrm{Pb}$ age determinations were carried out on a total of six samples taken from five different intrusive bodies. Lithology, sample number, and location are provided in Table 1 and Fig. 2. For each sample, six to seven zircons were carefully selected and treated according to the criteria outlined in Schaltegger et al. (2008). This resulted in a total of 37 single grain analyses (Table 2). The results of the $\mathrm{U}-\mathrm{Pb}$ age determinations based on these analyses are shown in concordia diagrams in Fig. 6. Because of the often very small analytical uncertainties obtained for individual ${ }^{206} \mathrm{~Pb} /{ }^{238} \mathrm{U}$ zircon dates $(0.1-0.3 \mathrm{Ma})$, the results do generally not overlap within their $2 \sigma$ errors and are represented as range of data rather than weighted mean ${ }^{206} \mathrm{~Pb} /{ }^{238} \mathrm{U}$ values (Fig. 2).

Hf isotope analyses were carried out on 15 zircons (Table 3) separated from four samples taken at four localities (Table 1) in order to obtain petrogenetic information concerning the magma sources of the studied plutons.

\section{Kopaonik intrusive (sample 11, Fig. 6a)}

This sample is an isotropic inequigranular quartzmonzonite taken from the south-eastern margin of the main Kopaonik intrusive body (Fig. 2). Six zircon analyses reveal ${ }^{206} \mathrm{~Pb} /{ }^{238} \mathrm{U}$ dates between 30.94 and $30.70 \mathrm{Ma}$ (Fig. 6a). The individual $2 \sigma$ errors are $\pm 0.01 \mathrm{Ma}$ due to high $\mathrm{Pb} * /$ $\mathrm{Pb}_{\mathrm{c}}$ (radiogenic/nonradiogenic lead) ratios (38-73) with

Table 1 Locality and lithology of the samples selected for $\mathrm{U}-\mathrm{Pb}$ age determination

\begin{tabular}{lllll}
\hline Sample & Lithology & Locality & Coordinates & \\
\hline $11^{*}$ & qz-monzonite & Kopaonik & 7485417 & 4795565 \\
$16^{*}$ & Granodiorite & Drenje & 7483641 & 4806274 \\
$21^{*}$ & Granodiorite & Željin & 7482818 & 4821570 \\
30 & qz-diorite & Željin & 7481290 & 4817210 \\
$509^{*}$ & Granodiorite & Golija & 7445900 & 4795450 \\
513 & Two-mica granite & Polumir & 7469329 & 4817635
\end{tabular}

Samples marked with an asterisk have also been analysed for $\mathrm{Hf}$ isotopic compositions (see Table 3). Coordinates are given in the MGI Balkan 7 Cartesian system. For location of the samples, see Fig. 2 uranium concentrations between 900 and 2,300 ppm. Except for analyses 11-1 and 11-6, none of the data overlap. Because there is no indication for inheritance of old lead, we interpret the single zircon data to reflect zircon growth over some $240 \mathrm{ka}$, i.e. from 30.94 to $30.70 \mathrm{Ma}$, or as mixing from two growths episodes approximated by a maximum age of 30.70 and a minimum age of $30.94 \mathrm{Ma}$, respectively. The $\varepsilon \mathrm{Hf}$ values measured for zircons 11-1, 11$3,11-4$, and 11-6 are relatively uniform and fall between 1.1 and 1.6 (Table 3).

\section{Drenje intrusive (sample 16, Fig. 6b)}

The sample is a medium-grained, equigranular granodiorite exhibiting a synmagmatic foliation defined by hornblende (Fig. 2). Compared to sample 11, the individual $2 \sigma$ errors of the ${ }^{206} \mathrm{~Pb} /{ }^{238} \mathrm{U}$ dates are slightly higher ( $\pm 0.01-0.03 \mathrm{Ma}$ ) because of low $\mathrm{Pb} * / \mathrm{Pb}_{\mathrm{c}}$ ratios. Based on the zircon ages for 16-1, 16-3, and 16-5, we were able to calculate a mean ${ }^{206} \mathrm{~Pb} /{ }^{238} \mathrm{U}$ date of $31.64 \pm 0.02 \mathrm{Ma}$ $(\mathrm{MSWD}=0.59)$. From the concordia plot one may infer two stages of zircon growth, one from 31.7 to $31.6 \mathrm{Ma}$ and a second one at around 31.2 Ma (Fig. 6b). Zircon 16-2 could indicate that the last growth occurred at $31.16 \mathrm{Ma}$. However, we prefer to interpret the entire time span given by the single grain analyses as indicating the duration of zircon growth between 31.66 and $31.16 \mathrm{Ma}$, or, alternatively, mixing of zircon from two growth episodes. The $500 \mathrm{ka}$ time span seems too long for the interpretation as protracted growth, a mixing hypothesis may therefore explain the data scatter better. The $\varepsilon \mathrm{Hf}$ values measured for zircons 16-1, 16-2, 16-3, and 16-4 (Table 3) show consistent values between 3.6 and 3.8, not indicating any old inherited zircon material.

\section{Željin intrusive (sample 21, Fig. 6c)}

The sample is a medium-grained, equigranular granodiorite. All six measured zircons yield concordant ages. Zircons 21-2 and 21-3 show large analytical uncertainties as well as potentially inaccurate ${ }^{206} \mathrm{~Pb} /{ }^{238} \mathrm{U}$ dates due to low $\mathrm{Pb} * / \mathrm{Pb}_{\mathrm{c}}$ ratios $(0.5-1.5)$. We therefore do not include them for the interpretation of the age of the intrusion. The oldest three zircons (21-1, 21-4, and 21-5) overlap within their $2 \sigma$ errors and give a mean ${ }^{206} \mathrm{~Pb} /{ }^{238} \mathrm{U}$ date of $31.46 \pm 0.03 \mathrm{Ma}$ $(\mathrm{MSWD}=0.26)$. Again, we prefer to interpret these data as indicating zircon growth over a time span of about $200 \mathrm{ka}$, i.e. from 31.62 (grain 4) to $31.42 \mathrm{Ma}$ (grain 6), or mixing from two growth periods. The $\varepsilon \mathrm{Hf}$ values obtained for zircons 21-1, 21-2, and 21-4 fall between 3.7 and 4.3. Zircon 21-3, however, reveals a $\varepsilon \mathrm{Hf}$ value of 1.9, suggesting that traces of an older, crust-derived Hf component may be present. 
Table 2 Results of U-Pb age determination by single zircon ID-TIMS; for the locations of the samples, see Fig. 2

\begin{tabular}{|c|c|c|c|c|c|c|c|c|c|c|c|c|c|c|c|c|c|}
\hline \multirow{3}{*}{$\begin{array}{l}\text { Sample } \\
\text { (Nr. on } \\
\text { Fig. 2) }\end{array}$} & \multirow[t]{3}{*}{ Zircon $^{\mathrm{a}}$} & \multirow{3}{*}{$\begin{array}{l}\text { Weight } \\
(\mathrm{mg})\end{array}$} & \multicolumn{3}{|c|}{ Concentrations } & \multirow[t]{3}{*}{$\mathrm{Th} / \mathrm{U}^{\mathrm{b}}$} & \multicolumn{8}{|c|}{ Atomic ratios } & \multicolumn{3}{|c|}{ Apparent ages (Ma) } \\
\hline & & & \multirow{2}{*}{$\begin{array}{l}\mathrm{U} \\
(\mathrm{ppm})\end{array}$} & \multicolumn{2}{|l|}{$\mathrm{Pb}$} & & \multirow{2}{*}{$\begin{array}{l}206 / \\
204^{\mathrm{c}}\end{array}$} & \multirow{2}{*}{$\begin{array}{l}207 / \\
206^{\mathrm{d}, \mathrm{e}}\end{array}$} & \multirow{2}{*}{$\begin{array}{l}\text { Error } 2 \sigma \\
(\%)\end{array}$} & \multirow{2}{*}{$\begin{array}{l}207 / \\
235^{\mathrm{d}}\end{array}$} & \multirow{2}{*}{$\begin{array}{l}\text { Error } \\
2 \sigma(\%)\end{array}$} & \multirow{2}{*}{$\begin{array}{l}206 / \\
238^{\text {d, e }}\end{array}$} & \multirow{2}{*}{$\begin{array}{l}\text { Error } \\
2 \sigma(\%)\end{array}$} & \multirow{2}{*}{$\begin{array}{l}\text { Error } \\
\text { Corr }\end{array}$} & \multirow{2}{*}{$\begin{array}{l}2061 \\
238^{\mathrm{e}}\end{array}$} & \multirow{2}{*}{$\begin{array}{l}207 / \\
235\end{array}$} & \multirow{2}{*}{$\begin{array}{l}207 / \\
206^{\mathrm{e}}\end{array}$} \\
\hline & & & & $\begin{array}{l}\text { Rad } \\
(\mathrm{ppm})\end{array}$ & $\begin{array}{l}\text { Nonrad } \\
\text { (pg) }\end{array}$ & & & & & & & & & & & & \\
\hline 11 & $11-1$ & 0.0081 & 961 & 4.84 & 1.03 & 0.14 & 2283.26 & 0.046744 & 0.20 & 0.030915 & 0.22 & 0.004797 & 0.05 & 0.42 & 30.85 & 30.92 & 43.42 \\
\hline & $11-2$ & 0.0053 & 1286 & 6.32 & 0.59 & 0.12 & 3477.16 & 0.046788 & 0.14 & 0.030880 & 0.15 & 0.004787 & 0.05 & 0.44 & 30.78 & 30.88 & 45.85 \\
\hline & $11-3$ & 0.0131 & 896 & 4.54 & 0.72 & 0.14 & 4945.70 & 0.046736 & 0.10 & 0.030999 & 0.12 & 0.004810 & 0.05 & 0.51 & 30.94 & 31.00 & 43.04 \\
\hline & $11-4$ & 0.0078 & 1138 & 5.61 & 0.59 & 0.12 & 4487.02 & 0.046631 & 0.11 & 0.030735 & 0.13 & 0.004780 & 0.05 & 0.47 & 30.74 & 30.74 & 37.81 \\
\hline & $11-5$ & 0.0026 & 2322 & 11.18 & 0.35 & 0.10 & 5177.13 & 0.046735 & 0.13 & 0.030764 & 0.14 & 0.004774 & 0.05 & 0.46 & 30.70 & 30.77 & 43.35 \\
\hline & $11-6$ & 0.0075 & 941 & 4.79 & 0.75 & 0.15 & 2854.68 & 0.046792 & 0.17 & 0.030955 & 0.19 & 0.004798 & 0.05 & 0.44 & 30.86 & 30.95 & 45.77 \\
\hline 16 & $16-1$ & 0.0138 & 274 & 1.43 & 1.34 & 0.43 & 911.62 & 0.046636 & 0.25 & 0.031637 & 0.26 & 0.004920 & 0.06 & 0.34 & 31.64 & 31.63 & 28.77 \\
\hline & $16-2$ & 0.0038 & 232 & 1.39 & 1.21 & 0.36 & 244.40 & 0.046832 & 0.85 & 0.031289 & 0.89 & 0.004846 & 0.09 & 0.51 & 31.16 & 31.28 & 39.02 \\
\hline & $16-3$ & 0.0093 & 153 & 0.83 & 1.32 & 0.43 & 365.24 & 0.047062 & 1.15 & 0.031944 & 1.20 & 0.004923 & 0.12 & 0.44 & 31.66 & 31.93 & 54.26 \\
\hline & $16-4$ & 0.0048 & 170 & 1.42 & 2.93 & 0.50 & 104.86 & 0.047254 & 1.22 & 0.031618 & 1.28 & 0.004853 & 0.10 & 0.66 & 31.21 & 31.61 & 64.42 \\
\hline & $16-5$ & 0.0023 & 1399 & 7.58 & 1.78 & 0.43 & 588.88 & 0.046718 & 0.31 & 0.031676 & 0.33 & 0.004918 & 0.07 & 0.33 & 31.62 & 31.66 & 33.94 \\
\hline & $16-6$ & 0.0020 & 1147 & 6.23 & 0.91 & 0.53 & 811.43 & 0.046769 & 0.26 & 0.031680 & 0.28 & 0.004913 & 0.08 & 0.39 & 31.59 & 31.67 & 39.02 \\
\hline 21 & $21-1$ & 0.0039 & 189 & 0.99 & 1.04 & 0.15 & 236.13 & 0.046574 & 2.22 & 0.031545 & 2.36 & 0.004912 & 0.17 & 0.83 & 31.59 & 31.54 & 34.41 \\
\hline & $21-2$ & 0.0048 & 166 & 0.80 & 2.52 & 0.11 & 110.60 & 0.046709 & 7.13 & 0.030232 & 7.77 & 0.004694 & 1.92 & 0.44 & 30.19 & 30.24 & 42.04 \\
\hline & $21-3$ & 0.0039 & 164 & 2.12 & 6.98 & 0.15 & 46.69 & 0.046646 & 5.08 & 0.031219 & 5.36 & 0.004854 & 0.39 & 0.74 & 31.22 & 31.21 & 38.23 \\
\hline & $21-4$ & 0.0037 & 213 & 1.10 & 1.64 & 0.14 & 165.33 & 0.046510 & 2.80 & 0.031528 & 2.99 & 0.004917 & 0.23 & 0.84 & 31.62 & 31.52 & 31.21 \\
\hline & $21-5$ & 0.0023 & 420 & 2.77 & 2.42 & 0.13 & 142.01 & 0.046804 & 1.59 & 0.031662 & 1.68 & 0.004906 & 0.13 & 0.71 & 31.55 & 31.65 & 46.31 \\
\hline & $21-6$ & 0.0027 & 282 & 2.27 & 2.72 & 0.14 & 105.42 & 0.046529 & 1.60 & 0.031349 & 1.70 & 0.004887 & 0.12 & 0.79 & 31.42 & 31.34 & 32.28 \\
\hline 30 & $30-1$ & 0.0160 & 224 & 1.14 & 0.85 & 0.12 & 1325.11 & 0.046567 & 0.37 & 0.031720 & 0.39 & 0.004940 & 0.05 & 0.55 & 31.77 & 31.71 & 34.25 \\
\hline & $30-2$ & 0.0085 & 471 & 2.27 & 0.68 & 0.07 & 1818.95 & 0.046548 & 0.26 & 0.031430 & 0.28 & 0.004897 & 0.03 & 0.52 & 31.54 & 31.47 & 33.72 \\
\hline & $30-3$ & 0.0062 & 154 & 0.81 & 0.62 & 0.08 & 489.10 & 0.046576 & 0.94 & 0.031668 & 1.00 & 0.004931 & 0.08 & 0.75 & 31.49 & 31.42 & 34.55 \\
\hline & $30-4$ & 0.0034 & 750 & 3.60 & 0.56 & 0.15 & 1404.92 & 0.046550 & 0.31 & 0.031476 & 0.34 & 0.004904 & 0.04 & 0.62 & 31.71 & 31.66 & 33.87 \\
\hline & $30-5$ & 0.0027 & 621 & 3.02 & 0.76 & 0.08 & 697.68 & 0.046550 & 0.62 & 0.031466 & 0.67 & 0.004903 & 0.05 & 0.78 & 31.53 & 31.46 & 33.79 \\
\hline & $30-6$ & 0.0086 & 677 & 3.28 & 0.61 & 0.08 & 2966.81 & 0.046628 & 0.16 & 0.031642 & 0.17 & 0.004922 & 0.03 & 0.47 & 31.65 & 31.63 & 37.81 \\
\hline 509 & $509-2$ & 0.0060 & 758 & 2.67 & 1.73 & 0.09 & 540.23 & 0.046285 & 1.25 & 0.020407 & 1.33 & 0.004940 & 0.11 & 0.71 & 20.58 & 20.51 & 24.10 \\
\hline & $509-3$ & 0.0050 & 915 & 3.31 & 1.83 & 0.12 & 506.05 & 0.046278 & 1.05 & 0.020000 & 1.12 & 0.004897 & 0.12 & 0.61 & 20.17 & 20.11 & 23.50 \\
\hline & $509-5$ & 0.0047 & 1280 & 4.38 & 1.30 & 0.12 & 928.47 & 0.046253 & 0.55 & 0.019986 & 0.59 & 0.004931 & 0.09 & 0.43 & 20.17 & 20.09 & 22.20 \\
\hline & $509-6$ & 0.0065 & 817 & 2.88 & 1.63 & 0.12 & 655.86 & 0.046226 & 0.88 & 0.020076 & 0.94 & 0.004904 & 0.15 & 0.49 & 20.27 & 20.18 & 20.76 \\
\hline & $509-7$ & 0.0051 & 318 & 2.81 & 10.12 & 0.11 & 50.83 & 0.045982 & 2.75 & 0.020096 & 2.90 & 0.004903 & 0.18 & 0.84 & 20.40 & 20.20 & 8.05 \\
\hline & $509-8$ & 0.0049 & 449 & 1.45 & 0.73 & 0.11 & 614.30 & 0.046394 & 0.71 & 0.020450 & 0.75 & 0.004922 & 0.06 & 0.79 & 20.58 & 20.56 & 29.57 \\
\hline & 509-9 & 0.0045 & 396 & 1.34 & 1.12 & 0.15 & 331.28 & 0.046208 & 1.36 & 0.020082 & 1.43 & 0.004940 & 0.11 & 0.72 & 20.29 & 20.19 & 19.54 \\
\hline 513 & $513-1$ & 0.0048 & 513 & 1.60 & 1.61 & 0.04 & 287.17 & 0.044133 & 7.89 & 0.016837 & 8.14 & 0.002767 & 0.40 & 0.65 & 17.81 & 16.95 & 35.02 \\
\hline & $513-2$ & 0.0053 & 880 & 2.49 & 0.91 & 0.26 & 912.46 & 0.045697 & 0.39 & 0.017372 & 0.42 & 0.002756 & 0.09 & 0.40 & 17.74 & 17.49 & 5.06 \\
\hline & $513-3$ & 0.0060 & 434 & 1.66 & 1.97 & 0.03 & 291.71 & 0.046774 & 1.92 & 0.021418 & 2.04 & 0.003321 & 0.19 & 0.68 & 21.37 & 21.52 & 49.44 \\
\hline & $513-4$ & 0.0065 & 333 & 1.78 & 6.21 & 0.03 & 80.66 & 0.046198 & 2.36 & 0.017954 & 2.48 & 0.002806 & 0.15 & 0.81 & 18.06 & 18.07 & 11.11 \\
\hline & $513-5$ & 0.0027 & 986 & 2.85 & 0.95 & 0.13 & 509.19 & 0.046292 & 0.58 & 0.017639 & 0.61 & 0.002764 & 0.07 & 0.49 & 17.79 & 17.75 & 44.21 \\
\hline & $513-6$ & 0.0030 & 662 & 8.06 & 1.68 & 0.08 & 863.28 & 0.049603 & 0.50 & 0.078419 & 0.54 & 0.011466 & 0.06 & 0.62 & 73.49 & 76.66 & 179.56 \\
\hline
\end{tabular}

\footnotetext{
${ }^{\text {a }}$ All zircons annealed-leached (Mattinson 2005), all single grains

${ }^{\mathrm{b}}$ Calculated on the basis of radiogenic ${ }^{208} \mathrm{~Pb} /{ }^{206} \mathrm{~Pb}$ ratios

c Corrected for fractionation and spike

d Corrected for fractionation, spike, blank, and common lead (Stacey and Kramers 1975)

e Corrected for initial Th disequilibrium, using an estimated $\mathrm{Th} / \mathrm{U}$ ratio of 4 for the melt
}

\section{Željin intrusive (sample 30, Fig. 6d)}

This is a quartzdiorite showing a weak magmatic foliation defined by hornblende, taken from the eastern part of the Željin intrusion (Fig. 2). The individual $2 \sigma$ errors on the
${ }^{206} \mathrm{~Pb} /{ }^{238} \mathrm{U}$ data are \pm 0.01 Ma due to high $\mathrm{Pb} * / \mathrm{Pb}_{\mathrm{c}}$ ratios (20-40), except for 30-3 and 30-5 with $\mathrm{Pb} * / \mathrm{Pb}_{\mathrm{c}}$ ratios of around 10 (Table 2) resulting in individual $2 \sigma$ errors of the ${ }^{206} \mathrm{~Pb} /{ }^{238} \mathrm{U}$ age of $\pm 0.03 \mathrm{Ma}$. We interpret these data to indicate zircon growth over some $250 \mathrm{ka}$, from 31.77 to 
Fig. 6 Concordia diagrams containing the results of zircon $\mathrm{U}-\mathrm{Pb}$ dating of six samples.

a Kopaonik quartz-monzonite. b Drenje granodiorite. c Granodiorite from the northern part of Željin. d Granodiorite of the southern part of Željin. e Granodiorite from the Golija mountain. f Granite from Polumir near Ušće. Ellipses show the analytical uncertainties of the individual analyses. The grey bands straddling the concordia quantify the ${ }^{238} \mathrm{U}$ and ${ }^{235} \mathrm{U}$ decay constant uncertainties. For location of the samples see Fig. 2
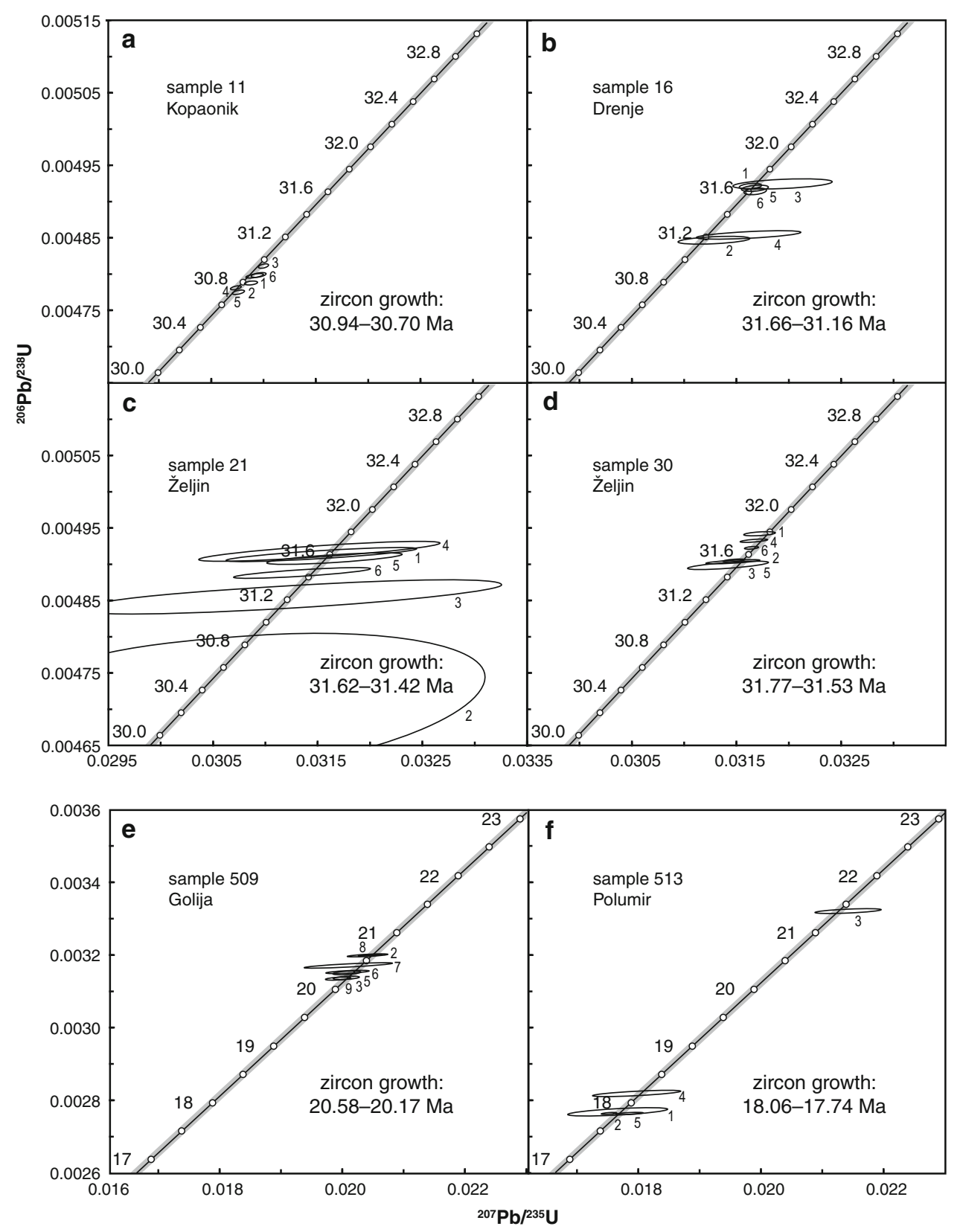

31.53 Ma, or mixing from two growth periods. The data possibly indicate that the younger zircons that exhibit smaller $\mathrm{Pb} * / \mathrm{Pb}_{\mathrm{c}}$ ratios incorporated less uranium due to fractionation in the magma source.

\section{Golija intrusive (sample 509, Fig. 6e)}

Seven zircons were analysed from this granodiorite. One analysis (509-7) yields an elevated value for common lead $(10.12 \mathrm{pg})$ and is thus excluded from the interpretation. The remaining analyses show individual $2 \sigma$ errors of the ${ }^{206} \mathrm{~Pb} /{ }^{238} \mathrm{U}$ data of $0.01-0.02 \mathrm{Ma}$. The ${ }^{206} \mathrm{~Pb} /{ }^{238} \mathrm{U}$ single grain dates fall between 20.58 and $20.17 \mathrm{Ma}$. At first sight, this time span of $400 \mathrm{ka}$ seems rather long for being interpreted as a time interval of zircon growth, therefore mixing of zircon material from two episodes of growth seems to be more likely. The $\varepsilon \mathrm{Hf}$ values are significantly lower in comparison with the samples of the substantially older Kopaonik suite (Kopaonik, Drenje, and Željin intrusion) and range between -0.7 and -2.7 .

\section{Polumir granite (sample 513, Fig. 6f)}

This two-mica granite is different from the other intrusions by the fact that it is the only one showing a high-temperature $\mathrm{C}-\mathrm{S}$ structures associated with a stretching lineation 
Table 3 Hf isotopic compositions of selected dated zircons

\begin{tabular}{|c|c|c|c|c|c|c|c|}
\hline Sample & Analysis & ${ }^{176} \mathrm{Hf} /{ }^{177} \mathrm{Hf}$ (normalized) & ${ }^{176} \mathrm{Hf} /{ }^{177} \mathrm{Hf}(\mathrm{T})$ & $\varepsilon \mathrm{Hf}(0)$ & $\varepsilon \mathrm{Hf}(\mathrm{T})$ & $\pm 2 \sigma$ & $\mathrm{T} 2(\mathrm{DM})(\mathrm{Ga})$ \\
\hline \multirow[t]{4}{*}{11} & $11-1$ & 0.282792 & 0.282792 & 0.71 & 1.43 & 0.5 & 0.94 \\
\hline & $11-3$ & 0.282798 & 0.282798 & 0.92 & 1.64 & 0.5 & 0.93 \\
\hline & $11-4$ & 0.282793 & 0.282793 & 0.74 & 1.46 & 0.5 & 0.94 \\
\hline & $11-6$ & 0.282784 & 0.282784 & 0.43 & 1.14 & 0.5 & 0.96 \\
\hline \multirow[t]{4}{*}{16} & $16-1$ & 0.282860 & 0.282860 & 3.12 & 3.83 & 0.5 & 0.80 \\
\hline & $16-2$ & 0.282857 & 0.282857 & 3.01 & 3.73 & 0.5 & 0.81 \\
\hline & $16-3$ & 0.282854 & 0.282854 & 2.90 & 3.62 & 0.5 & 0.81 \\
\hline & $16-4$ & 0.282854 & 0.282854 & 2.90 & 3.62 & 0.5 & 0.81 \\
\hline \multirow[t]{4}{*}{21} & $21-1$ & 0.282857 & 0.282857 & 3.01 & 3.73 & 0.5 & 0.81 \\
\hline & $21-2$ & 0.282873 & 0.282873 & 3.57 & 4.29 & 0.5 & 0.77 \\
\hline & $21-3$ & 0.282806 & 0.282806 & 1.20 & 1.92 & 0.5 & 0.91 \\
\hline & $21-4$ & 0.282862 & 0.282862 & 3.18 & 3.90 & 0.5 & 0.79 \\
\hline \multirow[t]{3}{*}{509} & $509-7$ & 0.282740 & 0.282740 & -1.13 & -0.68 & 0.5 & 1.06 \\
\hline & $509-8$ & 0.282718 & 0.282718 & -1.91 & -1.46 & 0.5 & 1.10 \\
\hline & $509-9$ & 0.282683 & 0.282683 & -3.15 & -2.70 & 0.5 & 1.17 \\
\hline
\end{tabular}

Errors of the measured ${ }^{176} \mathrm{Hf} /{ }^{177} \mathrm{Hf}$ ratios are given as external $2 \sigma$ reproducibility of standard measurements (i.e. \pm 0.5 ). $\varepsilon \mathrm{Hf}$ values and T(DM) model ages were calculated with $\left({ }^{176} \mathrm{Hf} /{ }^{177} \mathrm{Hf}\right) \mathrm{CHUR}(0)=0.282772$ and use present-day depleted mantle values of ${ }^{176} \mathrm{Hf} /{ }^{177} \mathrm{Hf}=0.283252$, ${ }^{176} \mathrm{Lu} /{ }^{177} \mathrm{Hf}=0.04145$ and a crustal ${ }^{176} \mathrm{Lu} /{ }^{177} \mathrm{Hf}=0.017$ (Blichert-Toft et al. 1997). For location of the samples, see Fig. 2

(Fig. 3). This solid-state fabric together with asymmetric boudinaged dykes observed in the host rocks (Fig. 3a) indicates top-to-the-north shearing along an extensional detachment that exhumed the Studenica Metamorphic Series and which was either active during the last stages of the intrusion and/or before the onset of substantial cooling of the Polumir granite (Fig. 3c). Two analyses, 513-3 and 513-6 (note that 513-6 is out of scale and not shown in Fig. 6f), are interpreted as inherited grains with ${ }^{206} \mathrm{~Pb} /{ }^{238} \mathrm{U}$ ages of 21.3 and 73.5 Ma, respectively. The remaining four zircons that we regard to have grown during the intrusion yield closely grouped ${ }^{206} \mathrm{~Pb} /{ }^{238} \mathrm{U}$ dates between 18.06 and 17.74 Ma. Three of them (513-1, 513-2, and 513-5) could be used to calculate a ${ }^{206} \mathrm{~Pb} /{ }^{238} \mathrm{U}$ mean-age of $17.760 \pm$ $0.048 \mathrm{Ma}(\mathrm{MSWD}=0.37), 513-4$ being statistically older with an age of $18.06 \mathrm{Ma}$. Again we interpret the data on these four zircons to indicate mineral growth during a magmatic event that occurred between 18.06 and 17.74 Ma, or, alternatively, being composed by mixing of an older and a younger age component in the zircon.

Interpretation and discussion of $\mathrm{U}-\mathrm{Pb}$ ages and Hf isotope data

All the dated samples provide evidence for protracted or poly episodic zircon growth over time spans of a few $10^{5}$ years, which can be resolved thanks to increased analytical precision in the ${ }^{206} \mathrm{~Pb} /{ }^{238} \mathrm{U}$ dates. Since zircon may already start to grow during magma assembly at deeper crustal levels and continue during ascent and emplacement into the middle to upper crust (Miller et al. 2007), it is reasonable to assume that the youngest zircon date approximates the age of emplacement (Schaltegger et al. 2009). However, we cannot completely rule out the effect of lead loss, despite the pre-treatment by chemical abrasion.

Comparison of the ages amongst the six different intrusions (Fig. 6) clearly reveals two age groups: (1) The group of Oligocene plutons intruded within a narrow time span between 31.77 and $30.70 \mathrm{Ma}$. The Kopaonik pluton is the youngest (sample 11, 30.94-30.70 Ma), and the remaining three (Drenje and the two analyses from Željin) cluster around $31.5 \mathrm{Ma}$. (2) The group of Miocene intrusions consists of the Golija granodiorite and the Polumir granite, which intruded at 20.58-20.17 and 18.06-17.74 Ma, respectively. While the existence of two age groups has been postulated by previous studies (Karamata et al. 1992; Knežević et al. 1995), our study shows that the I-type Željin and Drenje intrusions are of the same Oligocene age as, and possibly cogenetic with the I-type Kopaonik intrusion, as suggested by Cvetković et al. (2002) on petrogenetic grounds. This contradicts the supposed Miocene age of the Željin and Drenje intrusions inferred by the previous studies based on K-Ar dating (Karamata et al. 1992).

Two out of the three Oligocene intrusions, samples 16 and 21 from Drenje and Željin, respectively, record uniform $\varepsilon \mathrm{Hf}$ values ranging from 3.6 to 4.3 , whereas sample 11 of the Kopaonik quartzmonzonite shows distinctively lower values ranging from 1.1 to 1.6. The $\varepsilon \mathrm{Hf}$ values obtained for the Miocene Golija granitoid, on the other hand, are significantly lower in comparison with those 
obtained for the Oligocene intrusions, displaying $8 \mathrm{Hf}$ values ranging from -0.7 to -2.7 .

The positive $\varepsilon \mathrm{Hf}$ values of all the three samples taken from Oligocene intrusives, along with their metaluminous I-type geochemistry, suggest a moderate crustal influence in the origin and evolution of these granitoids, especially given the fact that these granitoids intrude an old (Paleozoic) crust. In this context, the primary melts of the Oligocene intrusives could have formed via partial melting of mantle-derived lower crustal protoliths. Regarding the significantly lower $\varepsilon \mathrm{Hf}$ values shown by the Miocene Golija granitoid, there are in principle at least two possible explanations: (1) This granitoid might have originated via melting of upper crustal material, but this possibility is unlikely given its distinctive I-type character. (2) The origin of the Golija intrusive could have involved an evolution that started with primary melts similar to those postulated for the Oligocene plutons. Such primary melts could have been modified either by assimilation of upper crustal material or, alternatively, by mixing with high-K calcalkaline to ultrapotassic basic magmas. Although these two hypotheses cannot be unequivocally tested without more data including geochemical modelling, the second possibility, namely that the lower $\varepsilon \mathrm{Hf}$ values of the Golija granitoid (and possibly for the Kopaonik quartzmonzonite as well) did result from mixing between an acid and a high$\mathrm{K}$ basic magma is supported by the following arguments: (1) the Golija granitoid is a metaluminous, I-type, high-K calc-alkaline rock, (2) it contains mafic enclaves which are believed to represent petrographic evidence of magma mixing processes (Didier and Barbarin 1991; Poli et al. 1996), (3) generally, the Serbian ultrapotassic rocks have very unradiogenic $\mathrm{Hf}$ isotopes $(\varepsilon \mathrm{Hf} \ll 0$; Prelević et al. 2010), similar to $\sim 500$-Ma-old continental crust (Rudnick and Gao 2003), and (4) the role of magma mixing during Tertiary magmatism in Serbia has already been advocated by Prelević et al. $(2001,2004)$ and Cvetković et al. (2007b).

Accordingly, the only intrusive that is certainly related to significant melting of upper crustal material is the Polumir S-type granite for which, unfortunately, there are no data on $\mathrm{Hf}$ isotopes.

\section{Zircon and apatite fission-track data}

Sampled material and presentation of data

The sampling strategy aimed at obtaining an evenly distributed dataset involving most of the intrusive bodies, including some volcanic rocks, taken at different altitudes. Fourteen samples from the different intrusive bodies together with two samples from the volcanic bodies within the
Ibar valley yielded fourteen apatite and fifteen zircon ages, twelve of them from both zircon and apatite. The analytical results are given in Table 4, the location of the samples in Fig. 2. The locations of additional yet unpublished data from (meta-) sedimentary rocks, taken from Schefer (2010), are shown in Fig. 2 and labelled 'Miocene' and 'pre-Miocene' zircon ages, respectively, in order to support the mapping of the outlines of the Miocene core complexes.

\section{Analytical techniques}

After conventional mineral separation (crushing, sieving, magnetic, and heavy liquid separation) samples were mounted in epoxy resin (apatite) and PFA Teflon (zircon). Revelation of fossil tracks was achieved by etching the polished zircon mounts in a NaOH-KOH eutectic melt at $210^{\circ} \mathrm{C}$. Apatite mounts were etched in $5 \mathrm{~N} \mathrm{HNO}_{3}$ at $20^{\circ} \mathrm{C}$ for $20 \mathrm{~s}$. Induced tracks in external detector muscovite were etched in $40 \% \mathrm{HF}$ for $45 \mathrm{~min}$ at $20^{\circ} \mathrm{C}$. Irradiation of samples was carried out at FRMII Garching (Technische Universität München, Germany). Neutron flux was monitored using CN5 (apatite) and CN1 (zircon) dosimeter glasses. Densities of spontaneous and induced tracks as well as lengths measurements for apatite (confined horizontal tracks and long axes of etch pits) were counted on a Zeiss Axioplan microscope equipped with an Autoscan ${ }^{\circledR}$ System at the University of Innsbruck. All samples have been analysed using the external detector method as described by Gleadow (1981). The fission-track central ages ( $\pm 2 \sigma$ error) (Galbraith and Laslett 1993) were calculated following the IUGS recommended approach of Hurford and Green (1983) with a zeta factor of $159 \pm 3.6$ (zircon, CN 1 glass) and $357 \pm 5.2$ (apatite, CN 5 glass) (analyst: B. Fügenschuh). Data processing was carried out using the TRACKKEY program (Dunkl 2002).

\section{Results}

All zircon central ages from the footwall of the D4b ductile normal faults range between 16.7 and $11.8 \mathrm{Ma}$ (Table 4). However, three samples that stem from the hanging wall of the D4b ductile normal faults (447, 460 and 461) yielded ages between 28 and 25 Ma. Sample 447 comes from a very small satellite body of the Kopaonik intrusion intruding the ophiolites near Jošanička Banja but separated from the main intrusive bodies shown in Fig. 2 by a D4b ductile normal fault. Samples 460 and 461 are daciticandesitic rocks in the Ibar valley that are part of the volcanics formed at shallow depth and never buried to greater depth (Fig. 2).

The apatite central ages obtained from the Kopaonik, Drenje, Željin, and Polumir intrusions in the footwall of the 


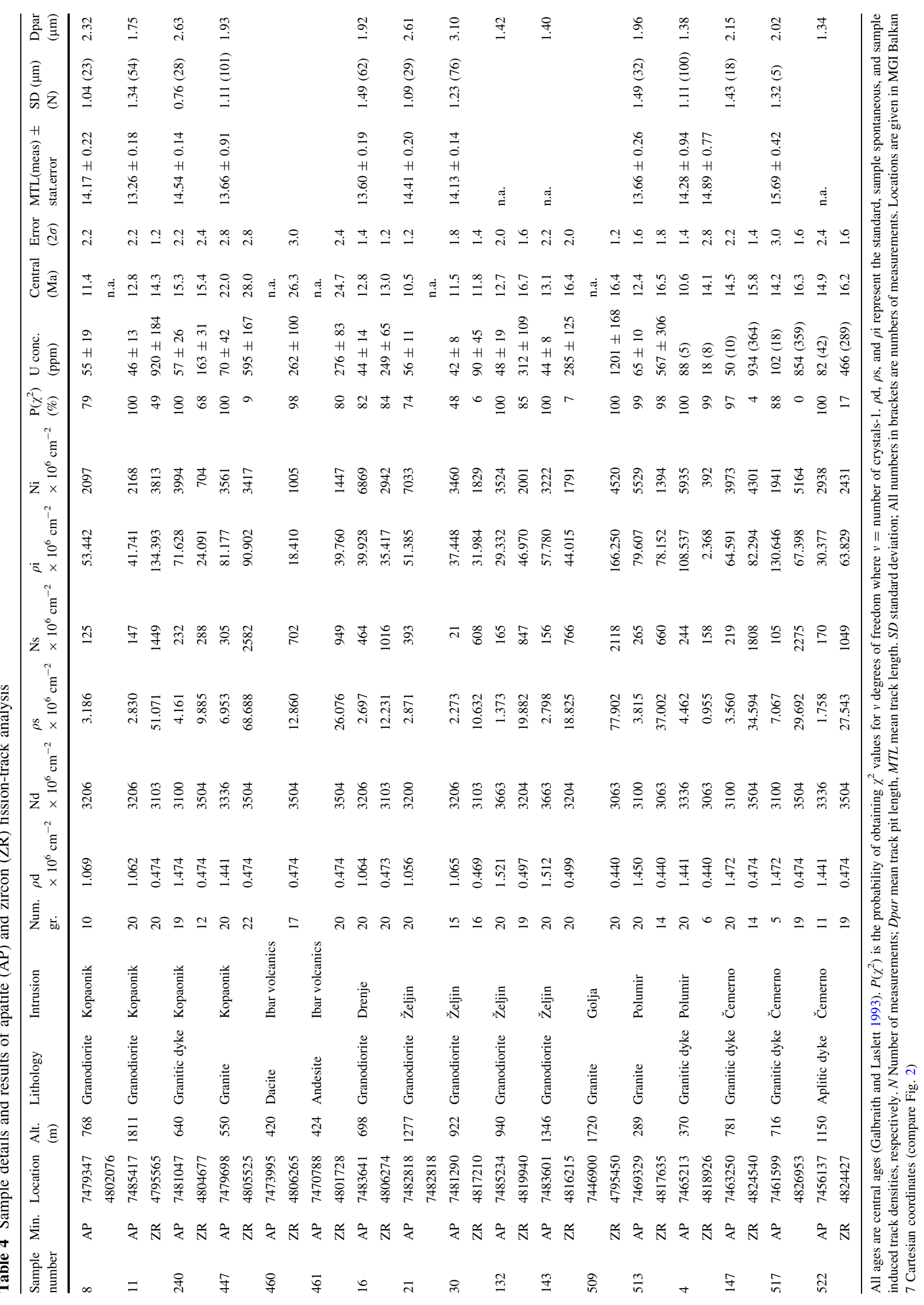


D4b ductile normal faults are only slightly younger compared to the zircon ages and range between 15.3 and 10.5 Ma. They all pass the Chi-square test. Mean track lengths range between 14.4 and $15.1 \mu \mathrm{m}$ (Table 4). The apatite age of sample 447 from the hanging wall of the $\mathrm{D} 4 \mathrm{~b}$ ductile normal faults is of course older ( $22 \mathrm{Ma})$; samples 460 and 461 did not reveal enough apatite grains to obtain a fission-track age.

Thermal modelling of the apatite fission-track data

Thermal modelling of apatite fission-track data obtained on intrusive rocks was carried out for the Oligocene Kopaonik, Drenje, and Željin intrusions (Fig. 7a, b and c), for the Miocene Polumir granite (Fig. $7 \mathrm{~d}$ and e), for a (presumed) Miocene dyke in Čemerno mountain (Fig. 7f), and for a (presumed) Oligocene sample taken from a small intrusion in Jošanica valley located near the Kopaonik main intrusion (Figs. 2, 7g). All modelled samples yielded a significant number of measured confined horizontal tracks. The grey envelopes show 'acceptable', the dark ones 'good' fits between modelled and measured data (Ketcham et al. 2007). The models are mathematically well defined since the goodness of fit (GOF) is always between 0.9 and 1 (c.f. "Appendix A").

All but the sample 447 from Jošanica valley (Fig. $7 \mathrm{~g}$ ) that was taken from the hanging wall of a D4b ductile normal fault show a similar cooling history, independent from the age of intrusion. Rapid cooling occurs from above the partial annealing zone for zircon, i.e. from around $300^{\circ} \mathrm{C}$, to some $80^{\circ} \mathrm{C}$ between 16 and $10 \mathrm{Ma}$, followed by rather slow cooling to surface temperatures for the last 10 Ma. Sample 447 (Fig. 7g), however, shows a different cooling history. Rapid cooling starts between 30 and $21 \mathrm{Ma}$, i.e. shortly after the (presumed) age of intrusion at around $31 \mathrm{Ma}$, and hence, significantly earlier compared to the other samples shown in Fig. 7. This implies that sample 447 must have intruded at a very shallow level close to the surface, in order to cool rapidly through both the ZPAZ and the APAZ immediately after intrusion. After $22 \mathrm{Ma}$, this sample cooled slowly from ca. $70^{\circ} \mathrm{C}$ to surface temperatures, as indicated by the modelling. Note that the enhanced cooling rate between 16 and $10 \mathrm{Ma}$, monitored for the other samples by the modelling, is totally absent in sample 447. This will further be discussed below.

Interpretation and discussion of the fission-track ages and thermal modelling

The most obvious characteristics of the fission-track data obtained from the Oligocene Kopaonik, Drenje, and Željin and the Miocene Polumir intrusions are that paired zircon and apatite ages display a small age difference within a
Fig. 7 Modelled thermal history and comparison between observed and predicted apatite fission-track parameters for selected samples from the main body of three different Oligocene intrusions $(\mathbf{a}, \mathbf{b}$, and $\mathbf{c}$ ), from the Miocene-age Polumir intrusion (d, e), from a granitic dyke from Čemerno mountain (f), and from a small Oligocene magmatic body in the Jošanica valley $(\mathbf{g})$. Horizontal black lines within individual models at $60-120^{\circ} \mathrm{C}$ bracket the partial annealing zone $(P A Z)$ for apatite within the temperature limits assigned by Laslett et al. (1987). The segments of the thermal histories at temperatures lower than $60^{\circ} \mathrm{C}$ only indicate a possible continuation of the thermal history because the annealing model is not sufficiently sensitive below $60^{\circ} \mathrm{C}$. The modelled t-T-paths are extended into the zircon partial annealing zone (Brandon et al. 1998) where the white squares represent the measured zircon fission-track central ages of the modelled samples including their $2 \sigma$ errors. Modelling of apatite ages and track-length distribution data were performed with the program HeFTy (Ketcham et al. 2003). Fission-track age, track-length distribution, and etch pit diameters (Dpar) as well as user-defined time-temperature boxes are used as input parameters. An inverse Monte Carlo algorithm with a multikinetic annealing model (Ketcham et al. 2007) was used to generate the time-temperature paths

given sample. This together with the fact that these samples all pass the Chi-square test strongly indicates that these ages are cooling ages. The samples indicate fast cooling from temperatures above the zircon partial annealing zone (ZPAZ) to temperatures below the apatite PAZ during the time span between 16 and $10 \mathrm{Ma}$. This is confirmed by the modelling results (Fig. 7, "Appendix A"), as well as by the unimodal distribution and mean track lengths of $>14 \mu \mathrm{m}$ of the confined horizontal tracks in apatite (Table 4). The exact age of the time interval of enhanced cooling, as indicated by the apatite zircon pairs, however, slightly differs. The time interval of enhanced cooling reveals a regional trend indicating that the timing of extensional unroofing becomes slightly younger when going from $\mathrm{S}$ to $\mathrm{N}$. Note that this interval of fast cooling observed in all the Oligocene intrusions, as indicated by fission-track age pairs and thermal modelling alike, significantly postdates the age of the intrusions at around 31 Ma that is documented by the $\mathrm{U}-\mathrm{Pb}$ zircon data (Table 2). With respect to an assumed intrusion depth of $6-8 \mathrm{~km}$, the retardation of cooling through the zircon annealing window after the intrusion implies a slightly elevated ambient geothermal gradient, probably related to the emplacement, cooling, and radioactive heat supply of the intrusion.

The Early Miocene Polumir intrusion yielded zircon fission-track ages of 16.5-14.1 Ma and apatite fission-track ages of 12.4-10.6 Ma (Table 4). As mentioned earlier, structural evidence (Fig. 3) suggests that the 18.06- to 17.74-Ma-old Polumir intrusion started to be deformed by extensional unroofing during the last stages of its emplacement or shortly thereafter. Since this unroofing is seen to have continued all the way into the brittle field the apatite fission-track age of $12 \mathrm{Ma}$ confines most of this extensional unroofing to have occurred during the 17-10 Ma time span. Hence, the timing of this Early to 
a Kopaonik, sample $11(\mathrm{~N}=54)$, good paths: 500
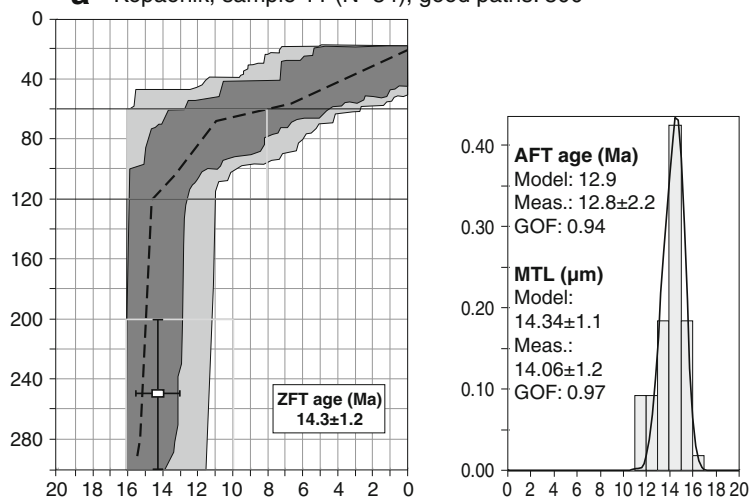

C Željin, sample $30(\mathrm{~N}=76)$, good paths: 500
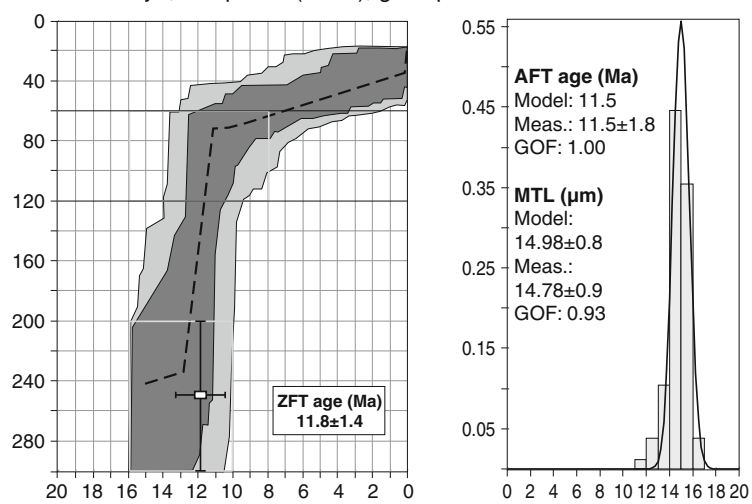

e Polumir, sample $4(\mathrm{~N}=100)$, good paths: 500
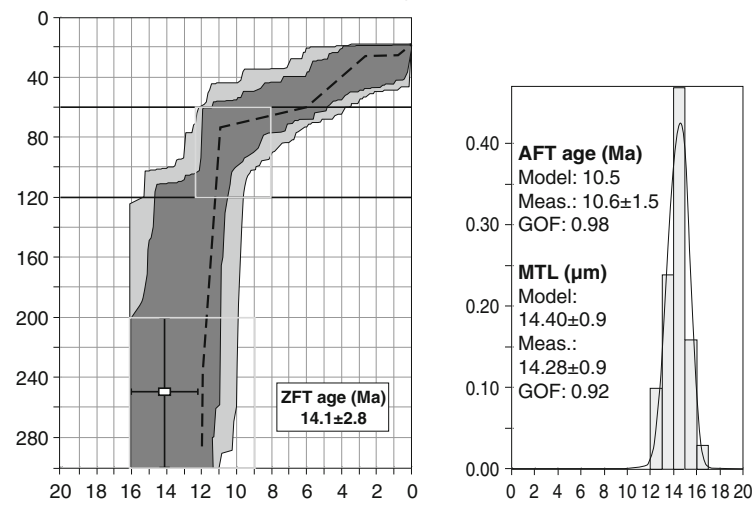

b Drenje, sample $16(\mathrm{~N}=62)$, good paths: 500
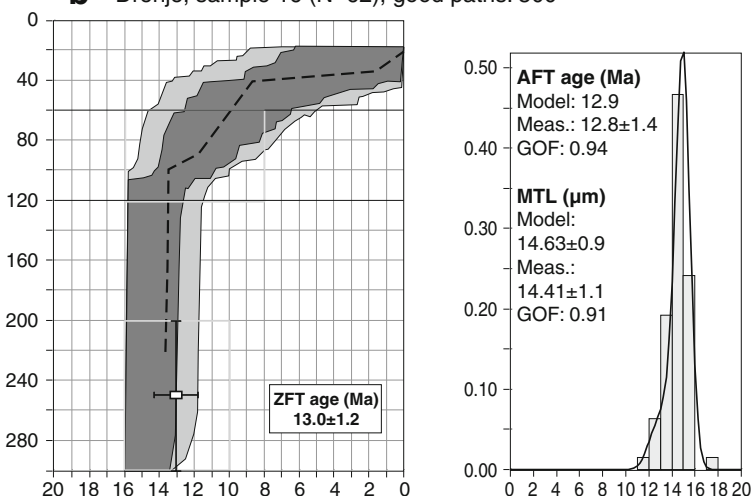

d Polumir, sample $513(\mathrm{~N}=32)$, good paths: 500
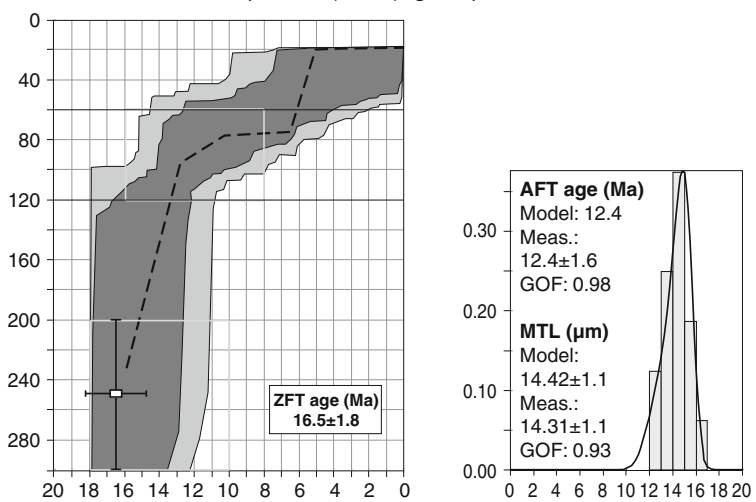

f Čemerno, sample $147(\mathrm{~N}=18)$, good paths: 500
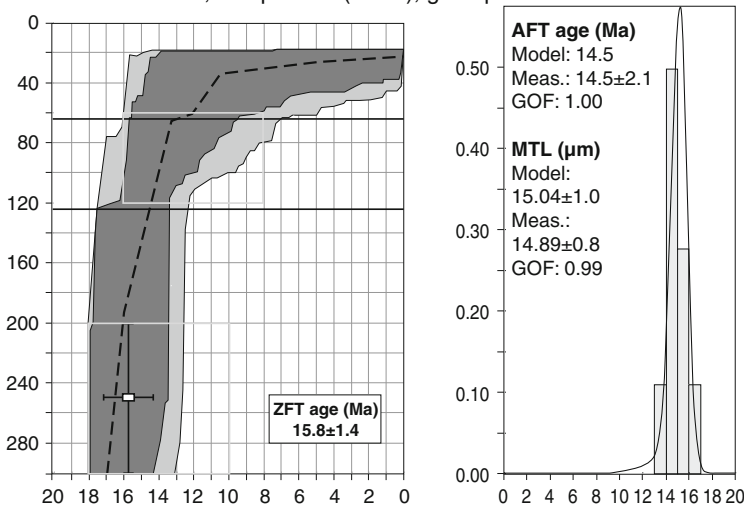

g Jošanica valley, sample $447(\mathrm{~N}=101)$, good paths: 500
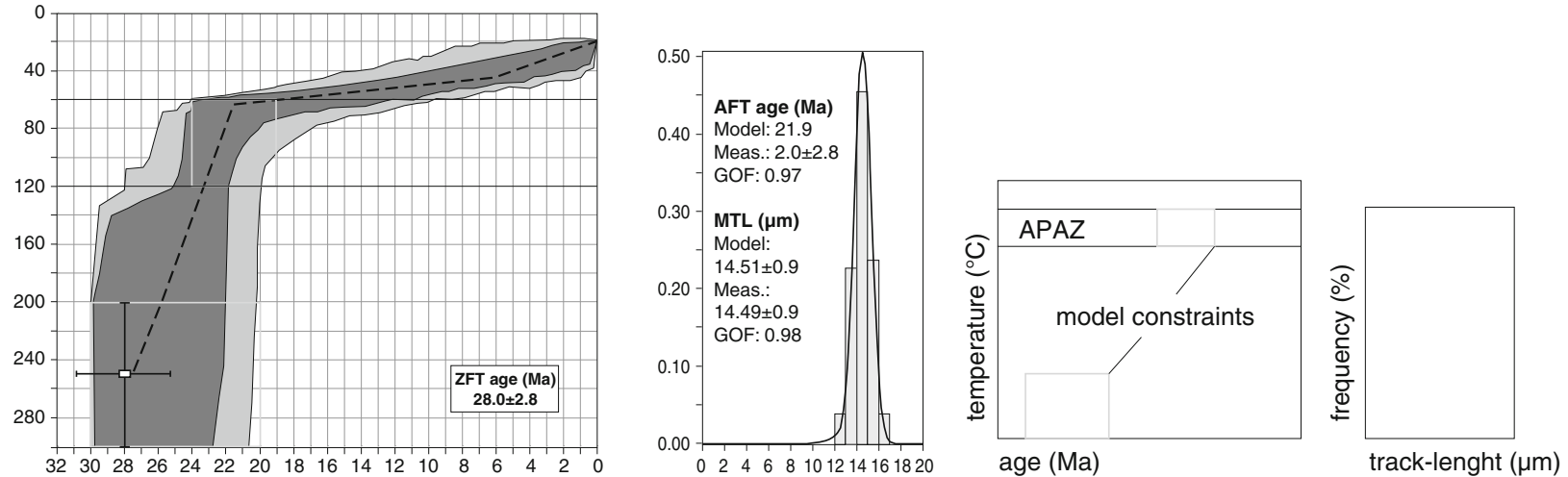
Middle Miocene period of rapid cooling, immediately following tectonically controlled exhumation in an extensional scenario near the Polumir granitoid, is comparable with the exhumation-related cooling history of the Kopaonik and Željin samples.

For the Golija intrusion, a similar and rather fast postemplacement cooling can be inferred from the combined U-Pb (20.58-20.17 Ma) and fission-track zircon ages $(16.4 \pm 1.2 \mathrm{Ma})$. Due to the lack of apatite fission-track data, the post-16 Ma evolution is not constrained.

Exhumation history of the granitoid intrusions of the inner dinarides

A cooling path was constructed for three particular intrusive bodies for which the results of fission-track modelling could be combined with the results of U-Pb dating (Fig. 8) obtained from the same samples.

The t-T-path for the Oligocene Kopaonik intrusion (sample 11 in Fig. 8) is most likely characterized by a first

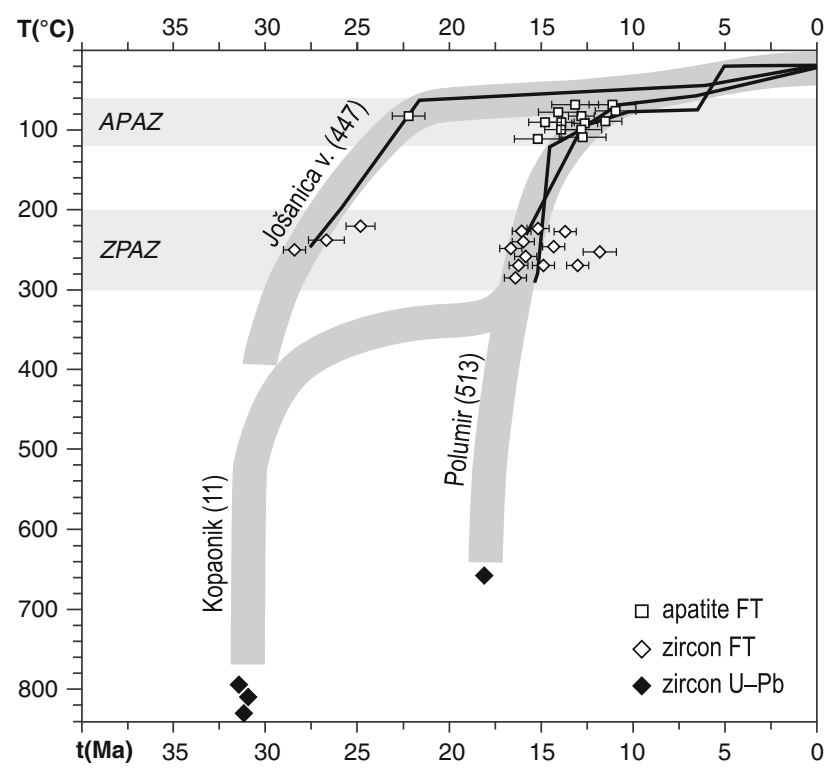

Fig. 8 Thermal histories of three of the analysed granitoids of southern Serbia, as inferred from the radiometric $\mathrm{U}-\mathrm{Pb}$ dating and the fission-track modelling presented in Fig. 7; the complete set of fission-track central ages obtained in the area is shown for comparison (c.f. Fig. 2; Table 4). The time-temperature paths (solid lines) correspond to the best-fit paths inferred from fission-track modelling (see Fig. 7) for samples 11 (Kopaonik), 513 (Polumir), and 447 (Jošanica valley); the thick grey lines represent an estimate of the complete t-T-evolution that also take into account the age and estimated temperature of crystallization of the zircons. The $\mathrm{U}-\mathrm{Pb}$ closure temperature corresponding to the zircon crystallization in sample 11 (Kopaonik quartz-monzonite) was assumed to be around $820^{\circ} \mathrm{C}$ (Lee et al. 1997). The S-type granite sample 513 (Polumir) must have intruded at lower temperatures due to its different melting temperature. ZPAZ and APAZ are the partial annealing zones of zircon and apatite, respectively period of rapid cooling due to heat conduction to the neighbouring rocks. Judging from the grade of regional metamorphism in the surrounding rocks (lowermost greenschist-facies conditions), depth of intrusion must have been within the upper crust. The ambient temperature of the country rocks is estimated to have been slightly above $300^{\circ} \mathrm{C}$, i.e. above the upper limit of the PAZ for zircon, corresponding to at least some $10 \mathrm{~km}$ depth, and hence somewhat deeper than suggested by the pressures of 0.5-1.5 kbar inferred from the related contact metamorphic aureole (Knežević et al. 1995). Because the onset of the second period of rapid cooling through the zircon and apatite partial annealing zones indicated by the modelling considerably postdates intrusion and its related first period of cooling by heat conduction, the Kopaonik intrusion must have remained at the ambient temperatures of the country rocks slightly above $300^{\circ} \mathrm{C}$ for more than $10 \mathrm{Ma}$. However, until the onset of the second period of fast cooling between 16 and $10 \mathrm{Ma}$, these initial parts of the time-temperature history are rather loosely constrained by our data. The second period of rapid cooling is well constrained, however. In combination with the structural (Figs. 3, 4) and metamorphic data (Schefer et al. 2008; Schefer 2010), this second period of rapid cooling can safely be interpreted as related to extensional unroofing in the footwall of normal faults that cut across the intrusion and surrounding metamorphic rocks (Figs. 2, 4). Final cooling to near-surface temperatures occurred again at lower rates of around $10^{\circ} \mathrm{C} / \mathrm{Ma}$ from $10 \mathrm{Ma}$ onwards.

The t-T-path of the Miocene Polumir granitoid revealed by fission-track data and modelling below $300^{\circ} \mathrm{C}$ (sample 513 in Fig. 8) is nearly identical with that of the Kopaonik intrusion. When combining the fission-track ages with the intrusion age obtained by the zircon U-Pb dating (Fig. 8), however, it becomes evident that this Miocene-age intrusion underwent one single period of rapid cooling. This confirms the view that Miocene-age exhumation by normal faulting overlapped with and immediately followed the Polumir intrusion, as is independently evidenced by the field data (see Fig. 3; Schefer et al. 2008; Schefer 2010). Fission-track central ages for zircon range from 16.7 to $11.8 \mathrm{Ma}$, those for apatite from 15.3 to $10.5 \mathrm{Ma}$ for all specimens analysed (Fig. 7), but for one specimen discussed below (sample 447). This indicates that fast cooling related to Miocene-age extensional unroofing affected all the intrusions analysed but that from which sample 447 was taken.

Sample 447 that exhibits a different cooling history was taken from a small magmatic body in the Jošanica valley that intrudes the Western Vardar ophiolites (Fig. 2), and hence, a shallower structural level. At first sight, given its close vicinity to the main Kopaonik intrusive body and the same macroscopic appearance, it seems that this outcrop 
might be a coherent part of the Kopaonik intrusion. Structurally, however, this small body is located in the hanging wall of the D4a ductile normal fault mapped in Fig. 2. This is supported by the fact that the zircon fissiontrack central age for this outcrop is $28 \mathrm{Ma}$, indicating cooling through the zircon PAZ shortly after the very probable Oligocene age of this intrusion. The fact that the sample fails the Chi-square test could indicate that the t-T-path of this sample is more likely due to cooling of the intrusion rather than recording tectonically induced rapid cooling during extensional unroofing. Hence, we propose that sample 447 stems from a much shallower part of the wider Kopaonik intrusive suite, which had already cooled to temperatures below the APAZ prior to Miocene extensional unroofing. This is independently supported by the fact that sample 447 is in close vicinity to the Oligoceneage extrusives (samples 460 and 461, Table 4) and volcaniclastics (32-29 Ma; Karamata et al. 1994) that crop out in the Ibar valley (Fig. 2).

Taken together the three cooling curves shown in Fig. 8 indicate that, after cooling of the Oligocene intrusions by heat conduction and before exhumation by Mid-Miocene extensional unroofing, the ambient temperatures differed by some $300^{\circ} \mathrm{C}$. This indicates that Mid-Miocene extension was very substantial in the area investigated; it led to tectonic omission in the order of $10 \mathrm{~km}$ across the associated Miocene-age D4 normal faults.

\section{Discussion of data within the regional geodynamic context}

Late Eocene to earliest Miocene (37-22 Ma) magmatic activity in the Balkan Peninsula

The group of Oligocene intrusions within the investigated area (Kopaonik, Drenje Željin) is part of a NW-SE striking alignment of granitoids that follows the inner Dinarides (Sava-Vardar Belt or Zone of Pamić et al. 2002a and Kovács et al. 2007, respectively) from northern Bosnia (Motajica intrusion, Ustaszewski et al. in press) all the way to southern Serbia (Fig. 9). Further to the SE, however, this same belt crosses the Sava suture and strikes into the Dacia Mega-Unit, the Rhodopes and the Strandja Unit, which together form the upper plate with respect to the Dinarides (Schmid et al. 2008). Geographically, this belt runs across southern Bulgaria and northern Greece all the way into westernmost Turkey (Fig. 9 and references given in Table 5). The granitoids intruded between Late Eocene (37 Ma) and earliest Miocene (22 Ma) times. One has to be aware, however, that the age dates reported in Table 5 were obtained by different techniques and at different levels of accuracy.
As shown in Fig. 9, age and location of the granitoids coincide with that of a series of basaltic rocks (high-K calcalkaline basalts, shoshonites and high-potassium volcanics; Cvetković et al. 2004a; Marchev et al. 2004; Prelević et al. 2005; 'basalts' in Fig. 9), volcanics and volcaniclastic basins, and additionally, non-volcanic sedimentary basins (e.g. Burchfiel et al. 2000, 2008; Dumurdzanov et al. 2005). Some of the basins are clearly associated with normal faulting and they date the onset of Aegean extension during Middle to Late Eocene times (e.g. Burchfiel et al. 2000, 2003; Kounov et al. 2004; Brun and Soukoutis 2007). The petrogenetic analyses of contemporaneous ultra-potassic volcanics (Prelević et al. 2005) in Serbia and in southern Bulgaria (Marchev et al. 2004) indicate that these volcanics were derived by melting a metasomatized mantle possessing a crustal signature. As already discussed above, it is reasonable to assume that this same mantle source may also have contributed to the genesis of the I-type granitoid intrusions such as the Kopaonik quartzmonzonite. This ultrapotassic magmatism is generally contemporaneous with the formation of acidic volcanic and plutonic rocks. Its contribution, however, is minor in the case of the Oligocene granitoids and volcanics because these rocks are calc-alkaline, but without very highpotassium contents.

For comparison, Fig. 9 also depicts the outlines of the occurrences of the older Tertiary basalts from the eastern Serbian ESPEMAR province (Paleocene to Mid-Eocene alkaline mafic volcanics). Most of these older Tertiary basalts are 60-50 Ma old according to the analyses that are mostly based on $\mathrm{K}-\mathrm{Ar}$ dating of phlogopite and whole rock dating (Cvetković et al. 2004a). Note that this eastern Serbian ESPEMAR province is systematically located in a more internal position with respect to the DinaridesHellenides (Fig. 9). The ESPEMAR province was interpreted to have formed during the final stages of subduction of the Vardar branch of Neotethys and initial collision with 'Europe' (Cvetković et al. 2004a, b). The occurrences in eastern Serbia spatially coincide with another and still older magmatic province, referred to as Banatite Belt or Apuseni-Banat-Timok-Sredna Gora Belt. This is a 92- to 78-Ma-old belt of calc-alkaline magmatism related to the subduction of a remnant of the Vardar branch of the Neotethys Ocean beneath the European continental margin during the Late Cretaceous (e.g. von Quadt et al. 2005). Note that, in contrast to the Late Eocene to earliest Miocene belt located within the Dinaridic lower plate, both these older magmatic belts are in a more internal position, i.e. they are confined to the upper ('European') plate with respect to the Sava suture.

The observation that the Late Eocene to earliest Miocene alignment of granitoids and associated features crosses the Sava suture implies that the last remnants of the 


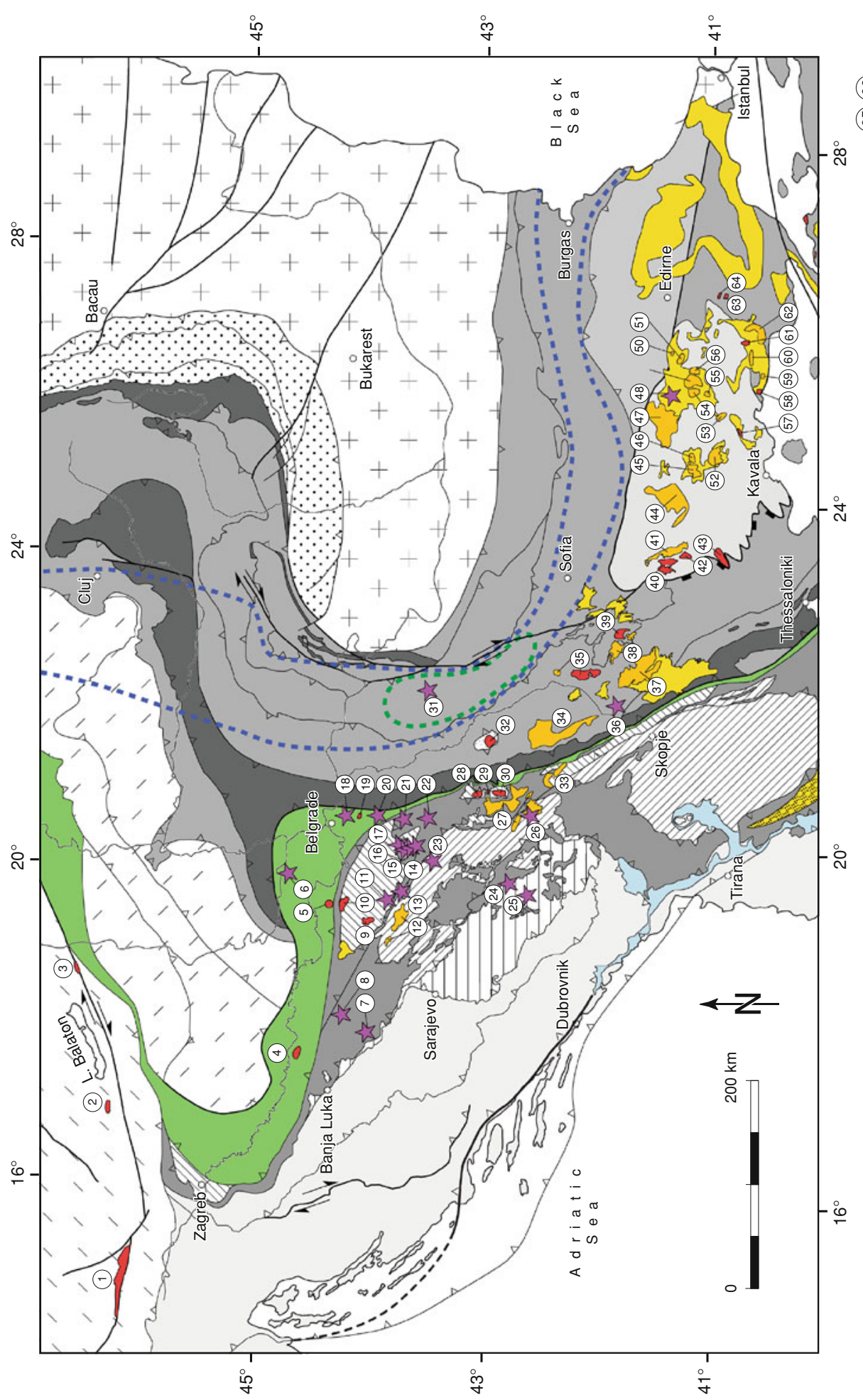

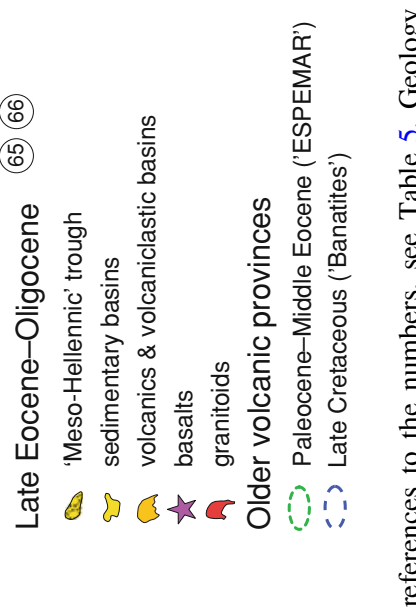

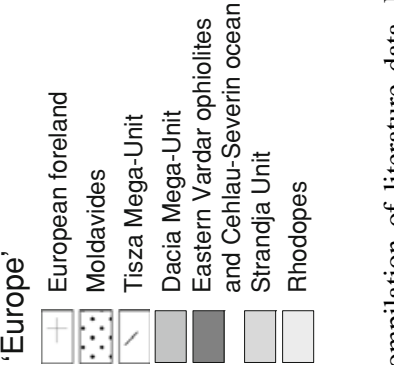

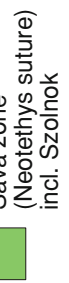

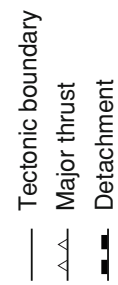

$\frac{0}{0}$

告

$\stackrel{\square}{ \pm}$

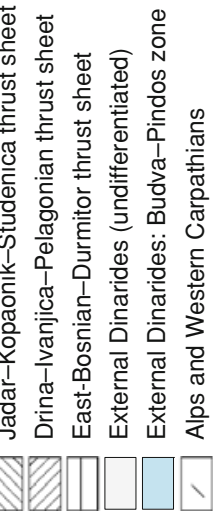

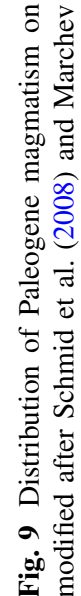


Table 5 References used for the compilation shown in Fig. 9

\begin{tabular}{|c|c|c|c|c|c|c|}
\hline $\mathrm{Nr}$ & Locality & Rock Type & Age (Ma) Error ${ }^{\mathrm{a}}$ & Method & Min. $^{a}$ & Literature \\
\hline \multicolumn{7}{|c|}{ Granitoids (red bodies) } \\
\hline 1 & Karawanken & Tonalite & $30-28$ & $\mathrm{~K}-\mathrm{Ar}$ & & Pamić and Palinkaš (2000) \\
\hline 2 & Zala & Tonalite & $35-27$ & $\mathrm{~K}-\mathrm{Ar}$ & & Benedek (2002) \\
\hline 3 & Velence & Andesite & $37-29$ & $\mathrm{~K}-\mathrm{Ar}$ & & Benedek (2002) \\
\hline 4 & Motajca & Granitoid & $26.7 \pm 0.1$ & $\mathrm{U}-\mathrm{Pb}$ & $\mathrm{Zr}$ & Ustaszewski et al. subm. \\
\hline 5 & Bogatić (well) & Tonalite & $44-36$ & $\mathrm{~K}-\mathrm{Ar}$ & Fsp & Pécskay unpubl. \\
\hline 5 & Bogatić (well) & Tonalite & $30.5 \pm 1.2$ & $\mathrm{~K}-\mathrm{Ar}$ & Bio & Pécskay unpubl \\
\hline 9 & Boranje & Granitoid & $34-29$ & $\mathrm{~K}-\mathrm{Ar}$ & Bio & Karamata et al. (1992) \\
\hline 10 & Cer & Granitoid & $30-22$ & $\mathrm{~K}-\mathrm{Ar}$ & Fsp & Karamata et al. (1994) \\
\hline 19 & Kosmaj & Granitoid & $30-29$ & $\mathrm{~K}-\mathrm{Ar}$ & Bio, wr & Karamata et al. (1994) \\
\hline 28 & Željin & Granitoid & $31.8-31.4$ & $\mathrm{U}-\mathrm{Pb}$ & $\mathrm{Zr}$ & This study \\
\hline 29 & Drenje & Granitoid & $31.7-31.2$ & $\mathrm{U}-\mathrm{Pb}$ & $\mathrm{Zr}$ & This study \\
\hline 30 & Kopaonik & Granitoid & $30.9-30.7$ & $\mathrm{U}-\mathrm{Pb}$ & $\mathrm{Zr}$ & This study \\
\hline 32 & Jastrebac & Granitoid & $37.3 \pm 5$ & $\mathrm{Rb}-\mathrm{Sr}$ & Bio & Cervenjak et al. (1963) \\
\hline 35 & Surdulica & Granodiorite & $29-33$ & $\mathrm{~K}-\mathrm{Ar}$ & Bio, wr & Ćebić (1990) \\
\hline 39 & Osogovo & Granitoid & $31.0 \pm 2$ & $\mathrm{U}-\mathrm{Pb}$ & $\mathrm{Zr}$ & Graf (2001) \\
\hline 40 & Central Pirin & Granitoid & $34.3 \pm 2$ & $\mathrm{U}-\mathrm{Pb}$ & $\mathrm{Zr}$ & Zagorchev et al. (1987) \\
\hline 42 & Teshovo & Granitoid & $32.0 \pm 0.2$ & $\mathrm{U}-\mathrm{Pb}$ & $\mathrm{Zr}$ & Jahn-Awe et al. (2010) \\
\hline 43 & Leptokaria & Granite & $32.0 \pm ?$ & $\mathrm{Rb}-\mathrm{Sr}$ & & Del Moro et al. (1988) \\
\hline 43 & Vrondou & Granodiorite & $33-23$ & $\mathrm{~K}-\mathrm{Ar}$ & $\mathrm{Hbl}$ & Marakis (1969) \\
\hline 57 & Xanthi & Granodiorite & $34-30$ & $\mathrm{U}-\mathrm{Pb}$ & $\mathrm{Zr}$ & Liati (1986) \\
\hline 58 & Maronia & Granite & $29.0 \pm ?$ & $\mathrm{Rb}-\mathrm{Sr}$ & & Del Moro et al. (1988) \\
\hline 58 & Skaloti & Granite & $33.0 \pm ?$ & $\mathrm{~K}-\mathrm{Ar}$ & & Marakis (1969) \\
\hline 61 & Kirki & Granite & $32.0 \pm ?$ & $\mathrm{Rb}-\mathrm{Sr}$ & & Del Moro et al. (1988) \\
\hline 61 & Lefkogia Granitis & Granodiorite & $28.0 \pm ?$ & $\mathrm{~K}-\mathrm{Ar}$ & & Marakis (1969) \\
\hline 63 & Halasmata & Granite & $32.0 \pm ?$ & $\mathrm{Rb}-\mathrm{Sr}$ & & Del Moro et al. (1988) \\
\hline 64 & Tris Vrisses & Granite & $35.0 \pm ?$ & $\mathrm{Rb}-\mathrm{Sr}$ & & Del Moro et al. (1988) \\
\hline \multicolumn{7}{|c|}{ Volcanics and volcaniclastic basins (orange bodies) } \\
\hline 12 & Srebrenica & Andesite & $31.7 \pm ?$ & $\mathrm{~K}-\mathrm{Ar}$ & Bio & Pamić (1997) \\
\hline 27 & Rogozna-Ibar & Volcaniclastics & $32-29$ & $\mathrm{~K}-\mathrm{Ar}$ & & Karamata et al. (1994) \\
\hline 33 & Kosovska Mitrovica & Volcaniclastics & $33-28$ & $\mathrm{~K}-\mathrm{Ar}$ & & Karamata et al. (1994) \\
\hline 34 & Lece & Volcaniclastics & $32-28$ & $\mathrm{~K}-\mathrm{Ar}$ & & Pamić and Balen (2001) \\
\hline 37 & Ovchepole & Volcanics & $32-29$ & $\mathrm{~K}-\mathrm{Ar}$ & & Dumurdzanov et al. (2005) \\
\hline 38 & Prekolnitsa & Volcanics & $34-33$ & $\mathrm{U}-\mathrm{Pb}$ & $\mathrm{Zr}$ & Kounov et al. (2004) \\
\hline 38 & Ruen & Volcanics & $32-29$ & $\mathrm{~K}-\mathrm{Ar}$ & & Harkovska and Pécskay (1997) \\
\hline 41 & Mesta & Volcaniclastics & $33.4 \pm 1.6$ & $\mathrm{~K}-\mathrm{Ar}$ & & Pécskay et al. (2000) \\
\hline 44 & Bratsigovo-Dospat & Volcaniclastics & $34.0 \pm 3$ & $\mathrm{~K}-\mathrm{Ar}$ & & Marchev et al. (2005) \\
\hline 45 & Perelik & Volcaniclastics & $32.9 \pm 1.2$ & $\mathrm{~K}-\mathrm{Ar}$ & & Pécskay et al. (1991) \\
\hline 46 & Levochevo & Volcaniclastics & $33.4 \pm 1.4$ & $\mathrm{~K}-\mathrm{Ar}$ & & Harkovska et al. (1998) \\
\hline 47 & Borovitsa & Volcaniclastics & $33-32$ & $\mathrm{Ar} / \mathrm{Ar}$ & & Singer and Marchev (2000) \\
\hline 49 & Sveti Iliya & Volcaniclastics & $35-31$ & $\mathrm{~K}-\mathrm{Ar}$ & & Lilov et al. (1987) \\
\hline 50 & Lozen & Volcaniclastics & $37-35$ & $\mathrm{~K}-\mathrm{Ar}$ & & Lilov et al. (1987) \\
\hline 51 & Madjarovo & Volcaniclastics & $33-31$ & $\mathrm{~K}-\mathrm{Ar}$ & & Lilov et al. (1987) \\
\hline 52 & Kotili-Vitinia & Volcaniclastics & $30.8 \pm 0.1$ & $\mathrm{U}-\mathrm{Pb}$ & & Ovtcharova et al. Unpubl. \\
\hline 53 & Kaloticho-Zlatograd & Volcaniclastics & $35-23$ & $\mathrm{~K}-\mathrm{Ar}$ & & Eleftheriadis and Lippolt (1984) \\
\hline 54 & Dambalak & Volcaniclastics & $31-29$ & $\mathrm{~K}-\mathrm{Ar}$ & & Georgiev et al. (2003) \\
\hline 55 & Zvezdel & Volcaniclastics & $31.9 \pm 0.5$ & $\mathrm{Ar} / \mathrm{Ar}$ & & Singer and Marchev (2000) \\
\hline 56 & Iran Tepe & Volcaniclastics & $37-35$ & $\mathrm{~K}-\mathrm{Ar}$ & & Lilov et al. (1987) \\
\hline
\end{tabular}


Table 5 continued

\begin{tabular}{|c|c|c|c|c|c|c|}
\hline $\mathrm{Nr}$ & Locality & Rock Type & Age (Ma) Error ${ }^{a}$ & Method & Min. $^{\mathrm{a}}$ & Literature \\
\hline 59 & Petrota & Volcaniclastics & $30-27$ & $\mathrm{~K}-\mathrm{Ar}$ & & Pécskay et al. (2003) \\
\hline 60 & Kirki-Esimi & Volcaniclastics & $33-22$ & $\mathrm{~K}-\mathrm{Ar}$ & & Pécskay et al. (2003) \\
\hline 62 & Loutros-Fere-Dadia & Volcaniclastics & $33-20$ & $\mathrm{~K}-\mathrm{Ar}$ & & Pécskay et al. (2003) \\
\hline \multicolumn{7}{|c|}{ Basalts (lila stars) } \\
\hline 6 & Fruška Gora & Trachyandesite & $34.0 \pm ?$ & $\mathrm{Rb}-\mathrm{Sr}$ & Fsp, Bio & Knežević et al. (1991) \\
\hline 7 & Veliki Majdan & Lamproite & $33.5 \pm 1.3$ & $\mathrm{~K}-\mathrm{Ar}$ & $\mathrm{Phl}$ & Cvetković et al. (2004a) \\
\hline 8 & Maglaj & Trachydacite & $30.1 \pm 1.5$ & $\mathrm{~K}-\mathrm{Ar}$ & Bio & Pamić et al. (2000) \\
\hline 11 & Zabrdica & Ol-lamproite & $25.6 \pm 1.0$ & $\mathrm{~K}-\mathrm{Ar}$ & wr & Cvetković et al. (2004a) \\
\hline 13 & Mionica & Lamproite & $29.1 \pm 1.1$ & $\mathrm{~K}-\mathrm{Ar}$ & wr & Cvetković et al. (2004a) \\
\hline 14 & Šilopaj & Basalt & $25.7 \pm 1.2$ & $\mathrm{~K}-\mathrm{Ar}$ & wr & Cvetković et al. (2004a) \\
\hline 15 & Mutanj & Basalt & $24.2 \pm 1.0$ & $\mathrm{~K}-\mathrm{Ar}$ & wr & Cvetković et al. (2004a) \\
\hline 16 & Boljkovac & Phl-trachybasalt & $29.7 \pm 1.1$ & $\mathrm{~K}-\mathrm{Ar}$ & wr & Cvetković et al. (2004a) \\
\hline 17 & Ozrem & Lamproite & $35.0 \pm 1.6$ & $\mathrm{~K}-\mathrm{Ar}$ & wr & Cvetković et al. (2004a) \\
\hline 17 & Ozrem & Andesite & $24.9 \pm 1.0$ & $\mathrm{~K}-\mathrm{Ar}$ & $\mathrm{Bt}$ & Cvetković et al. (2004a) \\
\hline 18 & Avala & Kersantite & $30.9 \pm 1.2$ & $\mathrm{~K}-\mathrm{Ar}$ & $\mathrm{Phl}$ & Cvetković et al. (2004a) \\
\hline 20 & Bukulja & Minette & $26.0 \pm 1.0$ & $\mathrm{~K}-\mathrm{Ar}$ & $\mathrm{Phl}$ & Cvetković et al. (2004a) \\
\hline 21 & Rudnik & Ol-Phl-lamproite & $30.2 \pm 1.1$ & $\mathrm{~K}-\mathrm{Ar}$ & Phl & Cvetković et al. (2004a) \\
\hline 21 & Rudnik & Minette & $31.9 \pm 1.2$ & $\mathrm{~K}-\mathrm{Ar}$ & Phl & Cvetković et al. (2004a) \\
\hline 22 & Borač & Phl-trachybasalt & $22.7 \pm 0.9$ & $\mathrm{~K}-\mathrm{Ar}$ & $\mathrm{Phl}$ & Cvetković et al. (2004a) \\
\hline 22 & Borač & Minette & $22.8 \pm 0.9$ & $\mathrm{~K}-\mathrm{Ar}$ & $\mathrm{Phl}$ & Cvetković et al. (2004a) \\
\hline 22 & Borač & Andesite & $23.9 \pm 1.0$ & $\mathrm{~K}-\mathrm{Ar}$ & $\mathrm{Hb} 180 \%$ & Cvetković et al. (2004a) \\
\hline 23 & Družetići & Analcimite & $23.9 \pm 2.1$ & $\mathrm{~K}-\mathrm{Ar}$ & wr & Cvetković et al. (2004a) \\
\hline 24 & Nova Varoš & Analcimite & $21.5 \pm 1.1$ & $\mathrm{~K}-\mathrm{Ar}$ & wr & Cvetković et al. (2004a) \\
\hline 25 & Trijebine & Analcimite & $23.0 \pm 1.3$ & $\mathrm{~K}-\mathrm{Ar}$ & wr & Cvetković et al. (2004a) \\
\hline 26 & Novi Pazar & Basaltic andesite & $29.8 \pm 1.2$ & $\mathrm{~K}-\mathrm{Ar}$ & wr & Cvetković et al. (2004a) \\
\hline 31 & Bogovina & Lamproite & $30.0 \pm 1.3$ & $\mathrm{~K}-\mathrm{Ar}$ & $\mathrm{Phl}$ & Cvetković et al. (2004a) \\
\hline 35 & Klinovac & Phl-trachybasalt & $32.7 \pm 1.3$ & $\mathrm{~K}-\mathrm{Ar}$ & wr & Cvetković et al. (2004a) \\
\hline 48 & Kardjali & High-Ba-trachybasalt & $33-29$ & $\mathrm{~K}-\mathrm{Ar}$ & & Marchev et al. (2004) \\
\hline
\end{tabular}

${ }^{a}$ if specified in original publication

Vardar branch of the Neotethys Ocean (Schmid et al. 2008) must have closed by Mid-Eocene times or earlier, in accordance with what is known from the literature (e.g. Pamić et al. 2002b; Ustaszewski et al. 2009, in press). Hence, it is clear that the Late Eocene to earliest Miocene magmatism is post-collisional with respect to the closure of the Vardar ocean. Since this magmatism is contemporaneous with the onset of extension in the Balkan area, various scenarios may be proposed. All of them fit with the petrological evidence including the positive $\varepsilon \mathrm{Hf}$ values:

(1) Post-collisional collapse of an overthickened orogen (e.g. Cvetković et al. 2004a), (2) Back-arc magmatism in relation to a more externally located subduction zone, with or without slab break-off of the Adriatic plate (e.g. Pamić et al. 2002a; Kovács et al. 2007), and/or, (3) Slab delamination (Bird 1979) caused by roll-back (Funiciello et al. 2006) of the former lower plate after collision, associated with foreland migration of thrusting within the external Dinarides. We exclude scenario (1) in view of the fact that compression in the Dinarides did not come to a halt after collision across the Sava Zone. Instead, there appears to be a shift of the site of compression to the more external parts of the Dinarides (and Hellenides) during the Late Eocene (Figs. 9a, b). The external Dinarides formed in Late Eocene to Neogene times (e.g. Skourlis and Doutsos 2003; Mikes et al. 2008; Korbar 2009), whereby much of the shortening (at least some $300 \mathrm{~km}$ in the area of Dubrovnik; see profile 5 of plate 3 in Schmid et al. 2008) took place by shortening within the Budva-Pindos pelagic realm of the Dinarides and Hellenides, respectively. Foreland migration of the site of compression is also well established for the Hellenides (e.g. van Hinsbergen et al. 2005).

However, in contrast to Kovács et al. (2007), we do not regard the Budva-Pindos zone as a site of subduction 
associated with an ophiolitic suture zone, since there is no evidence for the existence of a NW-ward continuation of either an oceanic or a non-oceanic Pindos zone into the Dinarides. Moreover, it is even uncertain if a 'Pindos Ocean' existed in the Pindos paleogeographic domain of Northwestern Greece (Schmid et al. 2008; Korbar 2009). Therefore, we also regard scenario (2), namely the installation of a second and more externally located oceanic subduction zone, unlikely. Rather, we prefer scenario 3, namely slab delamination and rollback of the Adriatic plate, whereby the Budva-Pindos zone merely represents an intra-continental site of compression (marked green in Fig. 9) that absorbs plate convergence. Note that this scenario is also in accordance with the evidence provided by Prelević et al. (2005) regarding the contemporaneous ultrapotassic volcanics being derived from a metasomatized mantle with a crustal signature.

We propose that after final closure of the Neotethys in the Eocene (Fig. 10a) the lithospheric mantle of the NE-ward subducted Adriatic plate started to delaminate (Bird 1979) and retreat. The thereby induced mantle flow (Funiciello et al. 2006; Piromallo et al. 2006) gave rise to mantle-dominated magmas with various amounts of crustal contamination. Although lacking delamination, a similar scenario has been described with respect to the opening of the Tyrrhenian basins (Faccenna et al. 2007), where the rapidly retreating Calabrian slab is continuously disrupted. In the case of the Dinarides, the delamination model shown in Fig. 10b allows for (1) the generation of chemically variable magmas, (2) magma emplacement in the lower (Adriatic) plate, and (3) one single and continuously evolving subduction zone associated with one and the same (Adriatic) mantle slab.

Teleseismic tomography (Bijwaard and Spakman 2000; Piromallo and Morelli 2003) indeed monitored a throughgoing high velocity body in the southern Dinarides and northern Hellenides, i.e. from about Dubrovnik southwards. However, these authors documented a ca. $300 \mathrm{~km}$ long gap towards the north (cf. Ustaszewski et al. 2008). This suggests that in the Northern Dinarides the Adriatic slab did break-off, while the central and southern Dinarides, as well as the Hellenides, are presently still characterized by roll-back and mantle delamination.

Concerning the connection of the Dinaridic Late Eocene to earliest Miocene magmatic belt with the contemporaneous Periadriatic intrusions s.str. of the Alps and the magmatic belt paralleling the Mid-Hungarian fault zone (localities 1,2 and 3 in Fig. 9), we emphasize that the subduction polarity in the Alps, including that within the Western Carpathians north of the Mid-Hungarian fault zone, merely representing the eastern prolongation of the Alps before Miocene lateral extrusion (Ratschbacher et al. 1991), is opposite to that of the Dinarides during the time
C present day

$E$

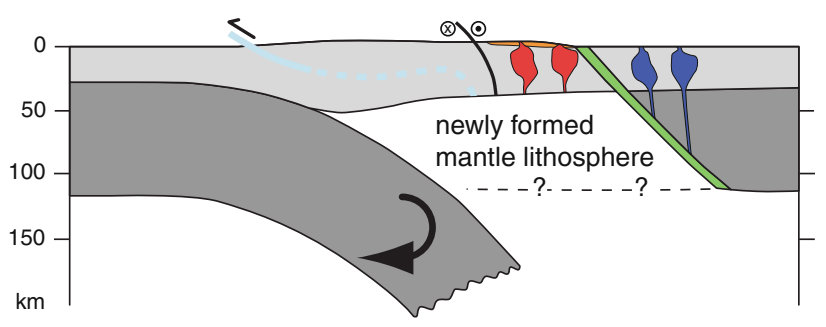

b $30 \mathrm{Ma}$

E
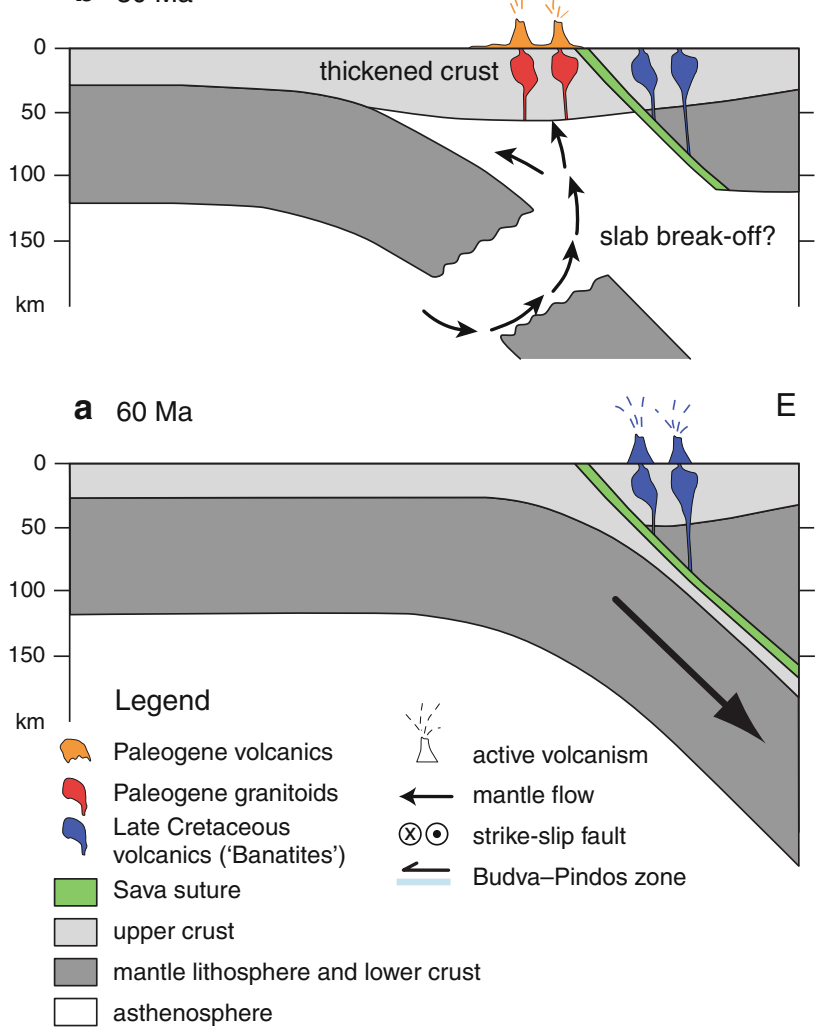

Fig. 10 East-West profile sketches illustrating the migration of magmatism from the upper plate (Tisza-Dacia and Rhodopes) into the lower plate (present-day Dinarides due to delamination of the lower plate (Adriatic) lithospheric mantle, possibly associated with slab break-off. Present-day geometry is that provided by the mantle tomography (Piromallo and Morelli 2003) and a by a crustal transect (Schmid et al. 2008)

span considered (Ustaszewski et al. 2008). Hence, in spite of the temporal coincidence, there cannot be a direct link between the Alpine-Mid-Hungarian magmatic belt and the Dinaridic-Hellenidic magmatic belt of which our area of investigation is a part. What is common to both, i.e. typical for the entire Periadriatic belt s.l., is the short distance between the site of subduction and the location of the magmatic arc, as well as the post-collisional scenarios. These two features, amongst others, led to the slab breakoff model first proposed by von Blanckenburg and Davies (1995) for the Periadriatic intrusions of the Alps. 
Miocene magmatic activity in the Dinarides

The Miocene Polumir intrusion (18 Ma) is part of a larger group of S-type granitoids in the Dinarides that includes a part of the Cer intrusive (albeit within an older I-type quartz monzonite; an age around $16 \mathrm{Ma}(\mathrm{K}-\mathrm{Ar})$ is reported for the S-type two-mica granite; Koroneos et al. 2010) and the twomica Bukulja intrusion (20-17 Ma are reported for the twomica granites; Cvetković et al. 2007b). It is uncertain, however, if the somewhat older I-type Golija intrusion with high-K affinity also belongs to this same suite. Regarding the Polumir intrusions, Vukov and Milovanović (2002) provided geochemical evidence to demonstrate partial melting of continental crust they interpreted to have formed in an extensional environment. This interpretation is supported by our own structural investigations (Fig. 3) and the fission-track data discussed above, which indicate the onset of extension during the last stages of granite emplacement or shortly thereafter (Fig. 8). Regarding the Cer and Bukulja intrusions (c.f. Fig. 9), Koroneos et al. (2010) and Cvetković et al. (2007b) proposed emplacement during the early stages of extension related to the formation of the Pannonian basin, the Bukulja intrusion being located in the footwall of a major core complex exhumed in early Miocene times (Marović et al. 2007). Hence, the location of these S-type granites at the southern margin of the Pannonian basin, their Early Miocene age, and their association with core complex formation all argue for them being located in the backarc area of the W-directed subduction of the European lithosphere beneath the Carpathians, widely invoked to explain extension and magmatism in the main part of the Pannonian basin (Csontos 1995; Seghedi et al. 2004). However, the locations of the Miocene S-type granitoids of the Inner Dinarides also come to lie into within the Late Eocene to earliest Miocene ( $>22 \mathrm{Ma}$ ) belt of predominantly I-type granitoids. This together with the fact that the Cer two-mica granite intrudes an older I-type quartz monzonite suggests that these S-type intrusions located at or close to the southern rim of the Pannonian basin may partly also have to do with them being located in the backarc area of the NE-directed subduction of the Adria plate. Hence, it is not clear yet as to what extent this Miocene magmatic activity in the inner Dinarides might also interfere with ongoing extension in the DinaridicHellenic back-arc during the Miocene.

\section{Conclusions}

(1) U-Pb (ID-TIMS) dating on single zircons from different intrusions in southern Serbia revealed two age groups, an Oligocene (31.77-30.70 Ma) and a Miocene (20.58-17.74 Ma) one. The Oligocene group
(Kopaonik, Drenje and Željin intrusive bodies) consists of I-type granitoids with positive $\varepsilon \mathrm{Hf}$ values of the zircons, indicating a moderate crustal influence in their origin, and it is proposed that this group formed via partial melting of mantle-derived lower crustal protoliths. The Miocene group consists of the S-type Polumir granite and the Golija intrusion that shows negative $\varepsilon \mathrm{Hf}$ values $(-0.7$ to -2.7$)$, generally indicating a higher crustal influence during magma generation.

(2) The zircon and apatite fission-track analyses show that the emplacement of all but one of the Oligocene intrusive bodies analysed occurred slightly above some $300^{\circ} \mathrm{C}$, i.e. within the upper crust. They cooled to the ambient temperatures and remained at this depth without further deformation for some $10 \mathrm{Ma}$ before the onset of rapid cooling due to unroofing by substantial extension between 16 and $10 \mathrm{Ma}$. The onset of exhumation in an extensional scenario led to core-complex formation and was contemporaneous with the intrusion of the S-type Miocene-age Polumir granite. Final cooling to near-surface conditions occurred at lower rates of around $100^{\circ} \mathrm{C} / \mathrm{Ma}$ from $11 \mathrm{Ma}$ onwards for both age groups.

(3) It is proposed that Late Eocene to Oligocene magmatism, which affects the Adria-derived lower plate units of the Dinarides may be caused by delamination of the Adriatic mantle from the overlying crust after the closing of the Neotethys Ocean and Adria-Europe collision, associated with intra-plate convergence within the external Dinarides, i.e. within the lower plate, that started during the Late Eocene.

(4) Miocene magmatism and core-complex formation at the southern rim of the Pannonian basin, believed to be mainly associated with back-arc extension, also affects a part of the mountainous areas of the internal Dinarides.

(5) A connection of the Dinaridic Late Eocene to earliest Miocene magmatic belt with other contemporaneous Periadriatic intrusions in the Alps and along the Mid-Hungarian fault zone, as often proposed in the literature, is unlikely because the subduction polarity in the Alps and in the Western Carpathians north of the Mid-Hungarian fault zone is opposite to that of the Dinarides during the Paleogene. Hence, in spite of the temporal coincidence, there cannot be a direct link between the Alpine-Mid-Hungarian magmatic belt and the Dinaridic-Hellenidic magmatic belt in Late Eocene to Oligocene times.

Acknowledgments We thank B. Schoene for his help with sample preparation and mass spectrometry. K. Ustaszewski gave valuable input to the regional geological discussion. Yet unpublished 
radiometric ages were made available by the courtesy of D. Prelević. This manuscript greatly benefited from the comments and suggestions by D. Bernoulli. Very thorough and constructive revisions by C. B. Burchfiel and A. von Quadt are highly appreciated. S. Schefer thanks the Freiwillige Akademische Gesellschaft Basel for supporting him and his family during the final stage of his $\mathrm{PhD}$ thesis. This project was financed by the Swiss National Science Foundation, Project No. 200020-109278 granted to S. M. Schmid, B. Fügenschuh, and S. Schefer.

\section{Appendix A: Fission-track dating}

Remarks regarding the interpretation of fission-track data

When interpreting fission-track results, we took into account that the central ages obtained by dating the minerals are not necessarily a geological meaningful age because the tracks produced by the decay of ${ }^{238} \mathrm{U}$ are not stable at all temperature conditions. There is a temperature range, the partial annealing zone (PAZ), at which the tracks in the mineral lattice become annealed. As a result of the annealing process, these tracks shorten and eventually disappear completely. The effective closure of the system lies within this PAZ and is dependent on the overall cooling rates and the kinetic properties of the minerals. The specific PAZ for apatite lies between 120 and $60^{\circ} \mathrm{C}$ (Green and Duddy 1989; Corrigan 1983). The PAZ for zircon is not equally well defined and a wide range of temperature bounds has been published. Yamada et al. (1995) suggest temperature ranges of ca. $390-170^{\circ} \mathrm{C}$, whereas Tagami and Dimitru (1996) and Tagami et al. (1998) report ca. $310-230^{\circ} \mathrm{C}$. Recently, in his overview on the zircon fissiontrack dating method, Tagami (2005) reported temperature ranges for the zircon closure temperature of ca. $300-200^{\circ} \mathrm{C}$. Accordingly, we use a value of $250 \pm 50^{\circ} \mathrm{C}$ for the closure temperature and a zircon PAZ of $300-200^{\circ} \mathrm{C}$.

\section{Apatite fission-track thermal modelling}

Fission tracks in apatite form continuously through time with an approximately uniform initial mean length of $\sim 16.3 \mu \mathrm{m}$ (Gleadow et al. 1986). Upon heating, tracks gradually anneal and shorten to a length that is a function of the time and maximum temperature to which the apatites were exposed. For example, tracks are completely annealed at a temperature of $110-120^{\circ} \mathrm{C}$ for a period of $10^{5}-10^{6}$ years (Gleadow and Duddy 1981). These annealing characteristics allow the generation of time-temperature paths by inverse modelling (e.g. Gallagher et al. 1998; Ketcham et al. 2003). As the resolution of the AFT thermo-chronometer is limited to the temperature range of $120-60^{\circ} \mathrm{C}$ (Laslett et al. 1987), the paths of the t-T envelope defined for the zones outside of this range are not necessarily representative for the real thermal evolution of a sample.

Modelling of the apatite age and track-length distribution data was carried out with the program HeFTy (Ketcham et al. 2003). Fission-track age, track-length distribution, and etch pits diameters (Dpar) as well as userdefined time-temperature (t-T) boxes are used as input parameters. An inverse Monte Carlo algorithm with a multikinetic annealing model (Ketcham et al. 2007) was used to generate the time-temperature paths. The algorithm generates a large number of time-temperature paths, which are tested with respect to the input data. The $\mathrm{t}-\mathrm{T}$ paths are forced to pass through the time-temperature boxes (constraints). The fitting of the measured input data and modelled output data are statistically evaluated and characterized by the value of 'goodness of fit' (GOF). A 'good' result corresponds to values $>0.5$, whereas a value of 0.05 or higher is considered to reflect an 'acceptable' fit between modelled and measured data.

It is important to remember that the 'best' thermal history obtained during this process is not necessarily the only possible one. Other thermal histories may match the observed data similarly well, and it is therefore imperative to consider as many other geological constraints as possible to determine the most likely path.

\section{References}

Benedek K (2002) Paleogene igneous activity along the easernmost segment of the Periadriatic-Balaton lineament. Acta Geol Hungarica 45:359-371

Bijwaard H, Spakman W (2000) Non-linear global P-wave tomography by iterated linearized inversion. Geophys J Int 141:71-82

Bird P (1979) Continental Delamination and the Colorado Plateau. J Geophys Res 84:7561-7571

Blichert-Toft J, Chauvel C, Albarède F (1997) Separation of Hf and $\mathrm{Lu}$ for high-precision isotope analysis of rock samples by magnetic sector-multiple collector ICP-MS. Contrib Mineral Petrol 127:248-260

Brandon MT, Roden-Tice MK, Garver JI (1998) Late Cenozoic exhumation of the Cascadia accretionary wedge in the Olympic Mountains, northwest Washington State. Geol Soc Am Bull 110:985-1009

Brković T, Malešević M, Urošević M, Trifunović S, Radanović Z, Dimitrijević M, Dimitrijević MN (1976) Geological map and explanatory text of the sheet Ivanjica. Savezni Geoloski Zavod, Beograd

Brun JP, Soukoutis D (2007) Kinematics of the Southern Rhodope Core Complex (North Greece). Int J Earth Sci 96:1079-1099

Burchfiel BC, Nakov R, Tzankov T, Royden L (2000) Cenozoic extension in Bulgaria and northern Greece: the northern part of the Aegean extensional regime. In: Bozkurt E, Winchester E, Piper JDA (eds) Tectonics and magmatism in Turkey and the surrounding area, vol 173. Geological Society (London) Special Publications, London, pp 325-352

Burchfiel BC, Nakov R, Tzankov T (2003) Evidence from the Mesta half-graben, SW Bulgaria, for the Late Eocene beginning of 
Aegean extension in the Central Balkan Peninsula. Tectonophysics 375:61-76

Burchfiel BC, Nakov R, Dumurdzanov N, Papanikolaou D, Tzankov T, Kotzev V, Todosov A, Nurce B (2008) Evolution and dynamics of the Cenozoic tectonics of the South Balkan extensional system. Geosphere. doi:10.1130/GES00169.1

Ćebić V (1990) Konačni izveštaj o geološko-petrološkom i geohemijskom izučavanju tercijarnog magmatskog kompleksa surduličke oblasti. Fond Geoinstituta, Beograd. (The final report on geological-petrological and geochemical investigations of the Tertiary magmatic complex of Surdulica area. Fund of Geoinstitute, Belgrade, in Serbo-Croatian)

Červenjak Z, Ferara G, Tongiorg E (1963) Age determination of some Yugoslav granites and granodiorites by the rubidium-strontium method. Nature 197:893-993

Chappell BJ, White AJR (1974) Two contrasting granite types. Pacific Geol 8:173-174

Corrigan JD (1983) Apatite fission-track analysis of Oligocene strata in South Texas, USA; testing annealing models. Chem Geol 104:227-249

Csontos L (1995) Tertiary tectonic evolution of the Intra-Carpathian area: a review. Acta Vulcan 7:1-13

Cvetković V (2002) Nature and origin of pyroclastic deposits of the Miocene Eruptive Complex of Borač (Central Serbia). Bull CXXV Acad Serbe Sci Arts Classe Sci Math et Sci Natur 342:209-215

Cvetković V, Pécskay Z (1999) The Early Miocene eruptive complex of Borač (central Serbia): volcanic facies and evolution over time. Extended abstract. Carpathian Geology 2000, October 11-14, 1999, Smolenice. Geol Carpathica 50:91-93

Cvetković V, Poli G, Resimić-Šarić K, Prelević D, Lazarov M (2002) Tertiary post-collision granitoid of Mt. Kopaonik (Serbia) Petrogenetic constraints based on new geochemical data. In: MichalíkJ, Šimon L, Vozár J (eds) Proceedings of XVII. Congress of Carpathian-Balkan Geological Association Bratislava, September 1st-4th 2002. Geol Carpathica 53

Cvetković V, Prelević D, Downes H, Jovanović M, Vaselli O, Pécskay Z (2004a) Origin and geodynamic significance of Tertiary postcollisional basaltic magmatism in Serbia (central Balkan Peninsula). Lithos 73:161-186

Cvetković V, Downes H, Prelević D, Jovanovic M, Lazarov M (2004b) Characteristics of the lithospheric mantle beneath East Serbia inferred from ultramafic xenoliths in Palaeogene basanites. Contrib Mineral Petrol 148:335-357

Cvetković V, Downes H, Prelević D, Lazarov M, Resimić-Sarić K (2007a) Geodynamic significance of ultramafic xenoliths from Eastern Serbia: Relics of sub-arc oceanic mantle? J Geodyn 43:504-527

Cvetković V, Poli G, Christofides G, Koroneos A, Pécskay Z, Resimić-Sarić K, Eric V (2007b) The Miocene granitoid rocks of Mt. Bukulja (central Serbia): evidence for pannonian extensionrelated granitoid magmatism in the northern Dinarides. Europ J Mineral 19:513-532

Del Moro A, Innocenti F, Kyriakopoulos C, Manetti P, Papadopoulos $\mathrm{P}$ (1988) Tertiary granitoids from Thrace (northern Greece)-Sr isotopic and petrochemical data. N J Miner Abh 159:113-135

Delaloye M, Lovrić A, Karamata S (1989) Age of tertiary granitic rocks of Dinarides and Vardar zone. 14th CBGA Congr Ext Abstr Sofia 1:1186-1189

Didier J, Barbarin B (1991) The different types of enclaves in granites-Nomenclature. In: Didier J, Barbarin B (eds) Enclaves and granite petrology, Developments in Petrology no. 13, Amsterdam, pp 19-23

Dumurdzanov N, Serafimovski T, Burchfiel BC (2005) Cenozoic tectonics of Macedonia and its relation to the South Balkan extensional regime. Geosphere 1:1-22
Dunkl I (2002) TRACKKEY: a windows program for calculation and graphical presentation of fission track data. Comput Geosci 18:3-12

Egli D (2008) Das Kopaonik-Gebirge in Südserbien-Stratigraphie, Strukturen und Metamorphose. MSc Thesis, University of Basel, Basel

Faccenna C, Funiciello F, Civetta L, D'Antonio M, Moroni M, Piromallo C (2007) Slab disruption, mantle circulation, and the opening of the Tyrrhenian basins. In: Beccaluva L, Bianchini G, Wilson M (eds) Geol Soc Am Spec Paper 418, pp 153-169

Funiciello F, Moroni M, Piromallo C, Faccenna C, Cenedese A, Bui HA (2006) Mapping mantle flow during retreating subduction: laboratory models analyzed by feature tracking. J Geophys Res 111:B03402. doi:10.1029/2005JB003792

Galbraith RF, Laslett GM (1993) Statistical models for mixed fissiontrack ages. Nucl Tracks Radiat Meas 21:459-470

Gallagher K, Brown R, Johnson C (1998) Fission-track anaysis and its applications to geological problems. Ann Rev Earth Plan Sci 26:519-572

Gapais D (1989) Shear structures within deformed granites: mechanical and thermal indicators. Geology 17:1144-1147

Georgiev V, Milovanov P, Monchev P (2003) K-Ar dating of the magmatic activity in the Momchilgrad volcano-tectonic depression. CR Acad Bulgare Sci 56:49-54

Gleadow AJW (1981) Fission-track dating methods-what are the real alternatives. Nucl Tracks Radiat Meas 5:3-14

Gleadow AJW, Duddy IR (1981) A natural long-term annealing experiment for apatite. Nucl Tracks 5:169-174

Gleadow AJW, Duddy IR, Green PF, Lovering JF (1986) Confined fission track lengths in apatite: a diagnostic tool for thermal history analysis. Contr Min Pet 94:405-415

Graf J (2001) Alpine Tectonics in Western Bulgaria: Cretaceous Compression of the Kraishte Region and Cenozoic Exhumation of the Crystalline Osogovo-Lisets Complex, PhD Thesis, ETH Zurich

Green PF, Duddy IR (1989) Some comments on paleotemperature estimation from apatite fission track analysis. J Petr Geol 12:111-114

Harkovska A, Pécskay Z (1997) The Tertiary magmatism in Ruen magmato-tectonic zone (W. Bulgaria)-A comparision of new KAr ages and geological data. In: Boev B, Serafimovski T (eds) Magmatism, Metamorphism and Metallogeny of the Vardar Zone and Serbo-Macedonian Massif. Faculty Mining Geology. Stip-Dojran, Rep, Macedonia, pp 137-142

Harkovska A, Marchev P, Machev P, Pécskay Z (1998) Paleogene magmatism in the Central Rhodope area, Bulgaria-a review and new data. Acta Vulcan 10:199-216

Hurford AJ, Green PF (1983) The zeta-age calibration of fission-track dating. Isotope Geosci 1:285-317

Jahn-Awe S, Froitzheim N, Nagel TJ, Frei D, Georgiev N, Pleuger J (2010) Structural and geochronological evidence for Paleogene thrusting in the Western Rhodopes (SW Bulgaria), subm. Tectonics 29:TC3008. doi:10.1029/2009TC002558

Karamata S, Delaloye M, Lovrić A, Knežević V (1992) Two genetic groups of tertiary granitic rocks of Central and Western Serbia. Ann Géol Péninsule Balkan 56:263-283

Karamata S, Pécskay Z, Knežević V, Memović E (1994) Origin and age of Rogozna (central Serbia) volcanics in the light of new isotopic data. Bull Acad Serb Sci 35:41-46

Ketcham RA, Donelick RA, Donelick M (2003) AFTSolve: a program for multi-kinetic modeling of apatite fission-track data. Am Miner 88:929-939

Ketcham RA, Carter A, Donelick RA, Barbarand J, Hurford AJ (2007) Improved measurement of fission-track annealing in apatite using c-axis projection. Am Miner 92:789-798

Knežević V, Szeki-Fux F, Steiger R, Pécskay Z, Boronihin VA, Karamata S (1991) Petrology of Fruška-Gora latites-volcanic 
precursors at the southern margin of the Pannonian basin. In: Geodynamic Evololution of the Pannonian Basin, Serb Acad Sci Arts 62, pp 243-259

Knežević V, Karamata S, Vasković N, Cvetković V (1995) Granodiorites of Kopaonik and contact metamorphic zone. In: Geology and Metallogeny of the Kopaonik Mt., Belgrade, pp $172-184$

Korbar T (2009) Orogenic evolution of the external dinarides in the NE Adriatic region: a model constrained by tectonostratigraphy of Upper Cretaceous to Paleogene carbonates. Earth Sci Rev 96:296-312

Koroneos A, Poli G, Cvetković V, Christofides G, Krstić D, Pécskay Z (2010) Petrogenetic and tectonic inferences from the study of the Mt Cer pluton (West Serbia). Geol Mag doi:10.1017/ S0016756810000476

Kounov A, Seward D, Bernoulli D, Burg JP, Ivanov Z (2004) Thermotectonic evolution of an extensional dome: the Cenozoic Osogovo-Lisets core complex (Kraishte zone, western Bulgaria). Int J Earth Sci 93:1008-1024

Kovács I, Csontos L, Szabó C, Bali E, Falus G, Benedek K, Zajacz Z (2007) Paleogene-early Miocene igneous rocks and geodynamics of the Alpine-Capathian-Pannonian-Dinaric region: an integrated approach. In: Beccaluva L, Bianchini G, Wilson M (eds) Cenozoic Volcanism in the Mediterranean Area, Geol Soc Am Spec Paper 418:93-112

Laslett GM, Green PF, Duddy IR, Gleadow AJW (1987) Thermal annealing of fission tracks in apatite: 2. A quantitative analysis. Chem Geol 65:1-13

Lee JKW, Williams IS, Ellis DJ (1997) $\mathrm{Pb}, \mathrm{U}$ and Th diffusion in natural zircon. Nature 390:159-162

Liati A (1986) Regional metamorphism and overprinting contact metamorphism of the Rhodope Zone, near Xanthi (N. Greece). PhD Thesis, Technische Universität Braunschweig

Lilov P, Yanev Y, Marchev P (1987) K-Ar dating of the eastern rhodopes paleogene magmatism. Geol Balcanica 17:49-58

Ludwig K (2005) Isoplot-a plotting and regression program for radiogenic isotope data. USGS Open File report, Boulder

Marakis G (1969) Geochronologic studies of some granites from Macedonia. Ann Géol Pays Héll 21:121-252

Marchev P, Raicheva R, Downes H, Vaselli O, Chiaradia M, Moritz R (2004) Compositional diversity of Eocene-Oligocene basaltic magmatism in the Eastern Rhodopes, SE Bulgaria: implications for genesis and tectonic setting. Tectonophysics 393:301-328

Marchev P, Kaiser-Rohrmeier M, Heinrich C, Ovtcharova M, von Quadt A, Raicheva R (2005) Hydrothermal ore deposits related to post-orogenic extensional magmatism and core complex formation: the Rhodope Massif of Bulgaria and Greece. Ore Geol Rev 27:53-89

Marović M, Djoković I, Toljić M, Spahić D, Milivojević J (2007) Extensional Unroofing of the Veliki Jastrebac Dome (Serbia). Ann Géol Péninsule Balkan 68:21-27

Mattinson JM (2005) Zircon U-Pb chemical abrasion ("CA-TIMS") method: Combined annealing and multi-step partial dissolution analysis for improved precision and accuracy of zircon ages. Chem Geol 220:47-66

Mikes T, Baldi-Beke M, Kazmer M, Dunkl I, von Eynatten H (2008) Calcareous nannofossil age constraints on Miocene flysch sedimentation in the Outer Dinarides (Slovenia, Croatia, Bosnia-Herzegovina and Montenegro). Geol Soc (London) Spec Pub 298:335-363

Miller JS, Matzel JEP, Miller CF, Burgess SD, Miller RB (2007) Zircon growth and recycling during the assembly of large, composite arc plutons. J Volcan Geotherm Res 167:282-299

Mojsilović S, Baklajić D, Djoković I (1978) Basic Geological Map of the SFRY, 1:100'000, Sheet Sjenica (K32-29), Savezni Geološki Zavod, Beograd (1960-1973)
Mojsilović S, Djoković I, Baklajić D, Rakić B (1980) Geology of the Sheet Sjenica (K32-29), Explanatory notes, Savezni Geološki Zavod, Beograd (1973, in Serbo-Croatian, English and Russian summaries)

Pamić J (1997) Volcanic rocks of the Sava-Drava interfluve and Baranja. Nafta Monograph, Zagreb

Pamić J, Balen D (2001) Tertiary magmatism of the Dinarides and the adjoining South Pannonian Basin, an overview. Acta Vulcan 13:9-24

Pamić J, Palinkas L (2000) Petrology and geochemistry of Paleogene tonalites from the easternmost parts of the Periadriatic Zone. Miner Petrol 70:121-141

Pamić J, Pécskay Z, Balen D (2000) Lower oligocene K-Ar ages of high-K calc-alkaline and shoshonite rocks from the North Dinarides in Bosnia. Miner Petrol 70:313-320

Pamić J, Balen D, Herak M (2002a) Origin and geodynamic evolution of Late Paleogene magmatic associations along the PeriadriaticSava-Vardar magmatic belt. Geodin Acta 15:209-231

Pamić J, Tomljenović B, Balen D (2002b) Geodynamic and petrogenetic evolution of Alpine ophiolites from the central and NW Dinarides: an overview. Lithos 65:113-142

Pécskay Z, Balogh K, Harkovska A (1991) K-Ar dating of the Perelik volcanic massif (Central Rhodopes, Bulgaria). Acta Geol Hungarica 34:101-110

Pécskay Z, Harkovska A, Hadjiev A (2000) K-Ar dating of Mesta volcanics (SW Bulgaria). Geol Balcanica 30:3-11

Pécskay Z, Eleftheriadis G, Koroneos A, Soldatos T, Christofides G (2003) K-Ar dating, geochemistry and evolution of the Tertiary volcanic rocks (Thrace, northeastern Greece). In: Eliopoulous DG (ed) Mineral exploration and sustainable development. Mill press, Rotterdam, pp 1229-1232

Piromallo C, Morelli A (2003) P wave tomography of the mantle under the Alpine-Mediterranean area. J Geophys Res 108:ESE1.1ESE1.23

Piromallo C, Becker TW, Funiciello F, Faccenna C (2006) Threedimensional instantaneous mantle flow induced by subduction. Geophys Res Lett 33:L08304. doi:10.1029/2005GL025390

Poli G, Tommasini S, Halliday AN (1996) Trace elements and isotopic exchange during acid-basic magma interaction processes. Trans R Soc Edinburgh Earth Sci 87:225-232

Prelević D, Cvetković V, Foley SF (2001) Composite igneous intrusions from Serbia; two case studies of interaction between lamprophyric and granitoid magmas. Tertiary magmatism in the Dinarides. Acta Vulcan 13:145-157

Prelević D, Foley SF, Cvetković V, Romer RL (2004) Origin of minette by mixing of lamproite and felsic magmas in Veliki Majdan, Serbia. J Petrol 45:759-792

Prelević D, Foley SF, Romer RL, Cvetković V, Downes H (2005) Tertiary ultrapotassic volcanism in Serbia: constraints on petrogenesis and mantle source characteristics. J Petrol 46:1443-1487

Prelević D, Foley SF, Stracke A, Romer RL, Conticelli S (2010) Hf isotopes in Mediterranean lamproites: mixing of melts from asthenosphere and crustally contaminated lithosphere. Lithos. doi:10.1016/j.lithos.2010.07.007

Ratschbacher L, Frisch W, Linzer H-G, Merle O (1991) Lateral extrusion in the Eastern Alps, 2, structural analysis. Tectonics 10:257-271

Rosenberg CL (2004) Shear zones and magma ascent: A model based on a review of the tertiary magmatism in the Alps. Tectonics 23:TC3002. doi:10.1029/2003TC001526

Rudnick RL, Gao S (2003) Composition of the continental crust. In: Heinrich DH, Karl KT (eds) Treatise on geochemistry. Pergamon, Oxford, pp 1-64

Schaltegger U, Brack P (2007) Crustal-scale magmatic systems during intracontinental strike-slip tectonics: $\mathrm{U}, \mathrm{Pb}$ and $\mathrm{Hf}$ 
isotopic constraints from Permian magmatic rocks of the Southern Alps. Int J Earth Sci 96:1131-1151

Schaltegger U, Guex J, Bartolini A, Schoene B, Ovtcharova M (2008) Precise $\mathrm{U}-\mathrm{Pb}$ age constraints for end-Triassic mass extinction, its correlation to volcanism and Hettangian post-extinction recovery. Earth Planet Sci Lett 267:266-275

Schaltegger U, Brack P, Ovtcharova M, Peytcheva I, Schoene B, Stracke A, Marocchi M, Bargossi GM (2009) 700, 000 years of magma accretion, crystallization and initial cooling in a composite pluton recorded by zircon and titanite (Adamello batholith, northern Italy). Earth Planet Sci Lett 286:208-218

Schefer S (2010) Tectono-metamorphic and magmatic evolution of the Internal Dinarides (Kopaonik area, southern Serbia) and its significance for the geodynamic evolution of the Balkan Peninsula. PhD Thesis, University of Basel, Switzerland

Schefer S, Egli D, Frank W, Fügenschuh B, Ovtcharova M, Schaltegger U, Schoene B, Schmid SM (2008) Metamorphic and igneous evolution of the innermost Dinarides in Serbia. In: 6th Swiss Geoscience Meeting, Lugano. Abstract Volume, pp 60-61

Schefer S, Egli D, Missoni S, Bernoulli D, Fügenschuh B, Gawlick HJ, Jovanović D, Krystyn L, Lein R, Schmid SM, Sudar MN (2010) Triassic metasediments in the Internal Dinarides (Kopaonik area, southern Serbia): stratigraphy, paleogeographic and tectonic significance. Geol Carpathica 61:89-109

Schmid SM, Bernoulli D, Fügenschuh B, Matenco L, Schefer S, Schuster R, Tischler M, Ustaszewski K (2008) The AlpineCarpathian-Dinaridic orogenic system: correlation and evolution of tectonic units. Swiss J Geosci 101:139-183

Seghedi I, Downes H, Szakacs A, Mason PRD, Thirlwall MF, Rosu E, Pécskay Z, Marton E, Panaiotu C (2004) Neogene-Quaternary magmatism and geodynamics in the Carpathian-Pannonian region: a synthesis. Lithos 72:117-146

Shand SJ (1947) Eruptive rocks. Their genesis, composition, classification, and their relation to ore deposits, 3rd edn. Wiley, New York

Simić V (1956) Zur Geologie des Studenicagebietes (Südwestserbien). Vesnik Bull Serv Geol Geophys 12:5-66

Singer B, Marchev P (2000) Temporal evolution of arc magmatism and hydrothermal activity including epithermal gold veins, Borovitsa caldera, southern Bulgaria. Econ Geol 95:1155-1164

Skourlis K, Doutsos T (2003) The Pindos Fold-and-thrust belt (Greece): inversion kinematics of a passive continental margin. Int J Earth Sci 92:891-903

Stacey JS, Kramers JD (1975) Approximation of terrestrial lead isotope evolution by a 2-stage model. Earth Planet Sci Lett 26:207-221

Tagami T (2005) Zircon fission-track thermochronology and applications to fault studies. Rev Miner Geochem 58:95-122

Tagami T, Dimitru TA (1996) Provenance and history of the Franciscan accretionary complex: constraints from zircon fission-track thermochronology. J Geophys Res 101:11353-11364

Tagami T, Galbreith RF, Yamada R, Laslett GM (1998) Revised annealing kinetics of fission tracks in zircon and geological implications. In: Van den Haute P, de Corte F (eds) Advances in fission-track geochronology. Kluwer Academic Publishers, Dordrecht, pp 99-114
Trajanova M, Pécskay Z, Itaya T (2008) K-Ar geochronology and petrography of the Miocene Pohorje Mountains batholith (Slovenia). Geol Carpathica 59:247-260

Urošević M, Pavlović Z, Klisić M, Brković T, Malešević M, Trifunović S (1970a) Basic Geological Map of the SFRY, 1:100’000, Sheet Novi Pazar (K34-3), Savezni Geološki Zavod, Beograd (1966)

Urošević M, Pavlović Z, Klisić M, Brković T, Malešević M, Trifunović S (1970b) Basic Geological Map of the SFRY, 1:100’000, Sheet Vrnjci (K34-18), Savezni Geološki Zavod, Beograd (1966)

Ustaszewski K, Schmid SM, Fuegenschuh B, Tischler M, Kissling E, Spakman W (2008) A map-view restoration of the AlpineCarpathian-Dinaridic system for the Early Miocene. Swiss J Geosci 101:S273-S294

Ustaszewski K, Schmid SM, Lugović B, Schuster R, Schaltegger U, Bernoulli D, Hottinger L, Kounov A, Fügenschuh B, Schefer S (2009) Late Cretaceous intra-oceanic magmatism in the internal Dinarides (northern Bosnia and Herzegovina): Implications for the collision of the Adriatic and European plates. Lithos 108:106-125

Ustaszewski K, Kounov A, Schmid SM, Schaltegger U, Frank W, Krenn E, Fügenschuh B (2010) Evolution of the Adria-Europe plate boundary in the northern Dinarides-from continentcontinent collision to back-arc extension. Tectonics (in press)

van Hinsbergen DJJ, Hafkenscheid E, Spakman W, Meulenkamp JE, Wortel R (2005) Nappe stacking resulting from continental lithosphere below subduction of oceanic and Greece. Geology 33:325-328

von Blanckenburg F, Davies JH (1995) Slab breakoff: A model for syncollisional magmatism and tectonics in the Alps. Tectonics 14:120-131

von Quadt A, Moritz R, Peytcheva I, Heinrich CA (2005) 3: Geochronology and geodynamics of Late Cretaceous magmatism and $\mathrm{Cu}-\mathrm{Au}$ mineralization in the Panagyurishte region of the Apuseni-Banat-Timok-Srednogorie belt, Bulgaria. Ore Geol Rev 27:95-126

Vukov M (1989) Petrology and geochemistry of Zeljin granitoid (in Serbian). PhD Thesis, Faculty of Mining and Geology, University of Belgrade

Vukov M (1995) Petrologic characteristics of granitoid rocks of Željin and Polumir. In: Geology and Metallogeny of the Kopaonik Mountain, Belgrade, pp 518-216

Vukov M, Milovanović D (2002) The Polumir granite-additional data on its origin. Ann Géol Péninsule Balkan 64:167-185

Yamada R, Tagami T, Nishimura S, Ito H (1995) Annealing kinetics of fission tracks in zircon: an experimental study. Chem Geol 122:249-258

Zagorchev I, Moorbath S, Lilov P (1987) Radiogeochronological data on the Alpine igneous activity in the western part of the Rhodope Massif. Geol Balcanica 17:59-71

Zelić M (2004) Tectonic history of the Vardar zone: constraints from the Kopaonik area (Serbia). PhD Thesis, Universita di Pisa, Italy

Zelić M, Levi N, Malasoma A, Marroni M, Pandolfi L, Trivić B (2010) Alpine tectono-metamorphic history of the continental units from Vardar zone: the Kopaonik Metamorphic Complex (DinaricHellenic belt, Serbia). Geol J 45:59-77. doi:10.1002/gj.1169 